\title{
ARTIGLES
}

\section{THREATENING INEFFICIENT PERFORMANCE OF INJUNCTIONS AND CONTRACTS}

\author{
IAN AYRES \\ KRISTIN MADISON ${ }^{\dagger}$
}

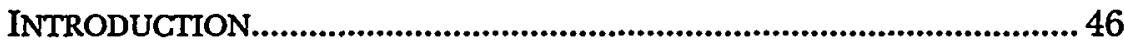

I. A UNIFYING THEORY OF PERFORMANCE THREATS............................58

A. The Motive to Threaten Inefficient Performance..............................59

B. When Will a Potential Defendant's Performance Threat Be

Credible? .....................................................................60 60

C. When Will a Plaintiff's Performance Threat Be Credible?.................64

D. When Do Performance Threats Cause Payoffs to Diverge From Make-

Whole Compensation? ......................................................... 68

II. HARNESSING PRIVATE INFORMATION TO DISCREDIT PERFORMANCE

THREATS

71

A. The Inalienable Injunction Option............................................... 72

B. The Defendant's Damage Adjustment Option-Private Additur...... 79

C. The Plaintiff's Damage Adjustment Option-Private Remittitur..... 82

III. SHOULD THREATS OF INEFFICIENT PERFORMANCE BE DETERRED?. 84

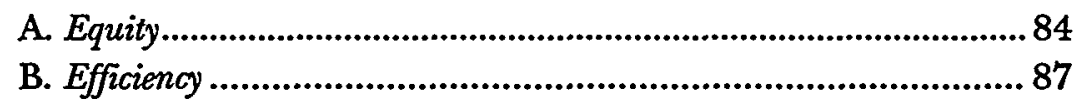

† Ian Ayres, William K. Townsend Professor, Yale Law School (ian.ayres@yale.edu); and Kristin Madison, J.D. Candidate, 2000, Yale Law School and Ph.D Candidate in Economics, 2001, Stanford University (kristin.madison@yale.edu). Barry Adler, Jonathan Baker, Lucian Bebchuk, Jennifer Brown, Adrienne Davis, Jill Fisch, Barbara Fried, Marcel Kahan, Candace Kovacic-Fleischer, Steve Parr, Ricki Revesz, Raphael Thomadsen, Peter Siegelman, Steven Thel, Jon Rork, Akila Weerapana, and seminar participants at American University, NYU, Stanford, and University of Tel Aviv law schools provided helpful comments. This material is based in part upon work supported under a National Science Foundation Graduate Fellowship received by Kristin Madison. Any opinions, findings, conclusions, or recommendations expressed in this publication are those of the authors and do not necessarily reflect the views of the National Science Foundation. 
1. Ante Effects on Defendant Precaution, Plaintiff Reliance,

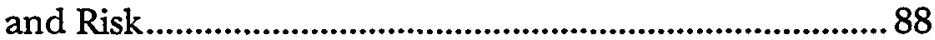

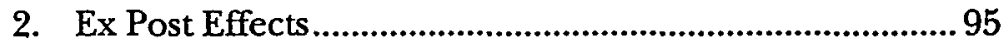

IV. MEANS OF ADDRESSING THREATS OF INEFFICIENT PERFORMANCE.. 98

A. Default Choice of Legal Regime.................................................. 98

B. Considerations in the Decision to Grant Injunctive Relief..............101

C. Judicial Review of Injunctive Settlements........................................ 103

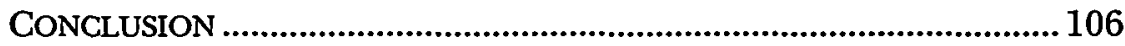

\section{INTRODUCTION}

Threats are often conditional promises to act inefficiently. The threatener in effect says: "I will do something that hurts you more than it helps me unless you pay me not to." Threatening inefficient action often in turn produces inefficiency because either the threatener follows through on her threat, resources are squandered in negotiating to avoid the threatened behavior, or the contracting parties take overly cautious steps to avoid being threatened. Contract scholars have long understood that this problem might arise when promisors threaten to breach. ${ }^{2}$ If contract damages are not sufficient to fully compensate a promisee for lack of performance, a promisor may threaten to breach in order to extract more favorable terms. For example, a seller may threaten to breach a supply agreement-even

${ }^{1}$ Under this definition, threats are made to induce payment. See Robert Hale, Coercion and Distribution in a Supposedly Non-Coercive State, 38 POL. SCI. Q. 470, 476 (1923) ("If I plan to do an act or to leave something undone for no other purpose than to induce payment, that might be conceded to be a "threat." "). In contrast, a promise to act efficiently is not a threat because the promisor does not seek payment and the promisee would not pay enough to stop the promisor from acting. Thus, the answer to the age-old tough-guy question: "Is that a threat or a promise?" may turn on whether the threatener/promisor seeks to change another person's behavior. Other characteristics of threatening behavior are explored in Ian Ayres \& Barry J. Nalebuff, Common Knowl edge as a Barrier to Negotiation, 44 UCLA L. REV. 1631 (1997).

${ }^{2}$ See, e.g., Saul Levmore, Strategic Delays and Fiduciary Duties, 74 VA. L. REV. 863, 870 (1988) ("Perhaps the most convincing argument for discouraging delay when the defendant's behavior is not unambiguously wrongful is that such delay threatens to deter desirable behavior by potential defendants."); Mary Lou Serafine, Note, Repudiated Compromise After Breach, 100 YALE L.J. 2229, 2229 (1991) ("The repudiated compromise arises when one party to a contract threatens to or does actually breach some term of a contract and, rather than take the problem to court, the parties agree to a compromise."). Threatening inefficient breach to negotiate a more favorable price is vividly illustrated by Austin Instrument, Inc. v. Loral Corp., 272 N.E.2d 533, 534 (N.Y. 1971) which concerned a subcontractor's "threat" to stop deliveries unless prices were increased. 
when it is clear that performance is efficient-solely to renegotiate a higher price. Because such renegotiations are often thought to be presumptively inefficient, the rules invalidating bad faith or opportunistic renegotiation attempt to deter promisors from making the initial threat.

A parallel problem has gone virtually unnoticed: threatening to perform. In this article, we will present two broad contexts where parties threaten inefficient performance of contractual promises or other legal duties solely to gain bargaining power in a subsequent negotiation:

1. A potential plaintiff who is owed a duty may, at times, seek inefficient injunctive relief instead of damages merely to induce a defendant (the person owing the duty) to pay an amount higher than expected courtawarded damages.

2. And, more perversely, a potential defendant who owes a duty to another may, at times, threaten to perform an inefficient duty merely to induce the plaintiff (the person owed the duty) to accept an amount less than expected court-awarded damages.

When a performance of some duty becomes inefficient (in the straightforward sense that the cost of performance is greater than the benefit), we will show that one side often will desire to threaten performance merely to gain bargaining power. The impulse to threaten inefficient performance does not connote, however, an ability to make credible threats. We will discuss conditions under which such threats are credible, giving rise not only to substantial negotiation costs but also to bargaining outcomes that diverge substantially from makewhole damages.

In the contractual context, promisees at times will inefficiently seek specific performance not because they value actual performance more than damages, but because they want to sell their court-ordered right to performance back to the promisor. These promisees represent to the court that monetary damages would be insufficient to make them whole and then-before the ink dries on the injunctionoffer a price to relieve the promisor of the court-ordered duty. Judge Posner foresaw just this possibility in declining to award an injunction to a coal seller: 
With continued production uneconomical, it is unlikely that an order of specific performance, if made, would ever actually be implemented.... [B]y offering [the seller] more than contract damages... [the buyer] could induce [the seller] to discharge the contract and release [the buyer] to buy cheaper coal .... Probably, therefore, [the seller] is seeking specific performance in order to have bargaining leverage with [the buyer], and we can think of no reason why the law should give it such leverage.

When promisors seek to breach what have become inefficient promises, promisees may seek specific performance merely to induce the promisors to pay more than expectation (make-whole) damages.

To understand the incentives promisees have to seek inefficient specific performance, consider a stylized variation on the facts of Peecyhouse. A miner has promised to return the topsoil on a farmer's strip-mined land to its original position. Imagine that the cost of moving the topsoil turns out to be $\$ 30,000$, but that the court is expected to award only diminution-in-value damages of $\$ 10,000$ if the miner fails to perform. If we also assume that the farmer's actual benefit from performance (moving the soil) is $\$ 8000$, the farmer has a strategic rationale for seeking specific performance of the contract. ${ }^{5}$ If the court awards specific performance, then the Nash bargaining solution $^{6}$ is for the miner to pay the farmer $\$ 19,000$ to avoid moving the soil. ${ }^{7}$ Even though $\$ 10,000$ in damages provides more compensation than $\$ 8000$ in make-whole relief, the farmer has an incentive to seek

${ }^{3}$ Northern Ind. Pub. Serv. Co. v. Carbon County Coal Co., 799 F.2d 265, 279-80 (7th Cir. 1986).

4 Peevyhouse v. Garland Coal \& Mining Co., 382 P.2d 109 (Okla. 1962).

${ }^{5}$ Judith Maute has suggested that the plaintiff's attorney may have elected not to seek specific performance in order to increase the size of his contingent fee. See Judith L. Maute, Peevyhouse v. Garland Coal \& Mining Co. Revisited: The Ballad of Willie and Lucille, 89 Nw. U. L. REV. 1341, 1449-50 (1995).

${ }^{6}$ The bargaining solution is the amount at which the bargaining parties ultimately settle. The settlement amount could conceivably be anywhere within the parties' bargaining range. However, in this Article we have chosen to use the Nash bargaining solution, which maximizes the product of the parties' bargaining gains. See, e.g., FranK STÄHILR, ECONOMIC GAMES AND STRATEGIC BEHAVIOUR: THEORY AND APPIICATION $40-41$ (1998) (describing the role of John Nash in the development of economic theory and the basic principles of his bargaining solution).

$7(8000+30,000) / 2$. An agreement to avoid performing the injunction creates a total surplus of $\$ 22,000$. The Nash solution splits this surplus between the two parties. The defendant pays the plaintiff $\$ 11,000$ less than she would have spent had she performed-the difference between the $\$ 30,000$ cost of performance and the $\$ 19,000$ payment to the plaintiff under the Nash solution. The plaintiff receives $\$ 11,000$ more than he would have received in the event of performance (the difference between the $\$ 19,000$ payment and the $\$ 8000$ benefit from performance). 
an inefficient injunction in order to increase his bargaining power. Scholars have mistakenly argued that "an injured party would not choose specific performance unless damages undercompensated the party. ${ }^{8}$ This simple example, however, shows that plaintiff/promisees may choose specific performance even when damages would overcompensate them. Although the equal division of the bargaining surplus implied by the Nash bargaining solution (which implicitly assumes equal bargaining power) may not apply to particular contexts, under a variety of alternative bargaining-power assumptions, the farmer/promisee will threaten inefficient performance as a bargaining chip.

Plaintiffs also seek inefficient injunctions outside of contractual settings. Indeed, the incentive to seek inefficient injunctions solely for settlement value is a possibility whenever the law gives aggrieved parties the option to seek an injunction instead of monetary damages. ${ }^{9}$ For example, consider the classic 1895 encroachment case of

${ }^{8}$ JAMES J. WHITE \& ROBERT S. SUMMERS, UNIFORM COMMERCIAL CODE 217 (4th ed. 1995) (footnote omitted).

${ }^{9}$ See Ian Ayres \& Peter Siegelman, (Econ)stitutional Law: Standing, Harm, and Revealed Preference (Aug. 29, 1999) (unpublished manuscript, on file with the University of Pennsylvania Law Review) for examples of several threats to seek injunctions in contexts outside of contracting. As the authors point out, a company may bring an antitrust action seeking an injunction to block a merger as being anticompetitive. The company seeks not to redress its own injury, but instead to capture a share of the gains the merging parties will achieve by selling back the injunction. See id. at $35 \mathrm{n} .71$. See also Joseph F. Brodley, Antilnust Standing in Private Merger Cases: Reconciling Private Incentives and Public Enforcement Goals, 94 MICH. L. REV. 1, 23 (1995), which states:

Frank Easterbrook and Daniel Fischel have taken the position that merger injunction actions are inherently inferior to damage actions. They argue that injunction actions create acute holdup problems because each plaintiff can threaten to block the acquisition unless paid the merger's full transactional value, a sum likely to exceed any threatened injury to the plaintiff.

Id. (citing Frank H. Easterbrook \& Daniel R. Fischel, Antitnest Suits by Targets of Tender Offers, 80 MICH. L. REV. 1155, 1169 (1982)).

Even constitutional claims may be used to extract a settlement. In designing an auction of Personal Communications Services frequencies, the Federal Communication Commission ("FCC") initially proposed rules giving bidding preferences to firms owned by women and/or minorities and to small businesses in the auctions for certain licenses. Telephone Electronics Corporation ("TEC"), whose $\$ 200$ million in annual revenues made it too large to qualify for bidding preferences as a small business, challenged the constitutionality of race and gender preferences. TEC's president was clear about why he had sought the injunction against the auctions: once it blocked the auctions, TEC could offer to drop its suit in exchange for an agreement with the FCC to grant it the bidding preference for which it had been ineligible. The FCC was about to grant TEC an exemption when TEC formed a joint venture with several larger firms and dropped its suit. See Ayres \& Siegelman, supra, at 36-38. 
Pile v. Pedrick. ${ }^{10}$ After being misinformed by a surveyor, Pedrick built a factory wall with a foundation that extended $1 \frac{3}{8}$ inches onto Pile's land (below the surface of the land). The court offered Pile a choice of either damages for the permanent trespass or a court order to remove the wall. Pile insisted upon the latter.

Imagine that Pedrick's cost of removing the wall was $\$ 10,000$, but the court's estimate of permanent trespass damages was only $\$ 500$. If we also assume that Pile's actual benefit from performance (removing the wall) was $\$ 0$, we can see Pile had a strategic rationale for seeking an injunction-even if Pile knew that tearing down the wall was inefficient. The Nash bargaining solution in the shadow of an injunction was for Pedrick to pay Pile $\$ 5000 .^{11}$ Even though performance was inefficient and damages provided more than make-whole relief, Pile had an incentive to seek an injunction in order to increase his bargaining power. As we will show more formally below, the incentive to seek inefficient injunctions is particularly strong when the likely courtawarded damages are substantially lower than the cost of performance.

Lest our gentle reader think that the incentive of plaintiffs to seek inefficient injunctions is merely another perverse, but other-worldly, implication of game theory, consider the two common law chestnuts of Edwards $v$. Allouez Mining Co. ${ }^{12}$ and Rieuman v. Burlington Northern Railroad $\mathrm{Co}^{13}$

In Edwards, the defendant, in 1874, "at a cost of some sixty thousand dollars erected a stamp mill on the banks of Hill creek."14 The operation of the mill necessitated depositing large quantities of sand on the bottom lands below. As Justice Cooley summarized:

The year following the erection of defendant's mill, complainant purchased a piece of land through which the creek runs a short distance below the mill, and upon which the mill as operated was depositing sand. The land was not purchased for use or occupation, but as a matter of speculation, and apparently under an expectation of being able to force defendant to buy it at a large advance on the purchase price. It was offered to defendant soon after the purchase, and though no price was named, the valuation which has been put upon it by complainant and his witnesses is from three to five times what it cost him, and this perhaps gives some in-

\footnotetext{
${ }^{10} 31$ A. 646 (Pa. 1895).

$(\$ 10,000+\$ 0) / 2$.

38 Mich. 46 (1878).

118 F.R.D. 29 (S.D.N.Y. 1987).

${ }^{14}$ Edwards, 38 Mich. at 48.
} 
dication what his expectations were. ${ }^{15}$

As Edward Yorio has noted: "[T]he peculiar facts of Edwards dramatize how equitable remedies may be used to extort overcompensatory settlements." Edwards represents a strategic "coming to the nuisance" in order to extort a supercompensatory payment.

For a more contemporary example, consider the facts of Rieoman. In this case, bonds issued in 1896 were secured with realty that by 1985 was worth billions of dollars more than the outstanding principal of the bonds. The terms of the bond mortgages, however, severely inhibited the sale and development of the realty. A class of bondholders brought suit "to enjoin the [defendant] Railroad from substituting other collateral for [the realty] by which the bond mortgages [were] secured. ${ }^{n 7}$ The court expressly endorsed the bondholders' right to "hold up" the defendant for an immediate "premium" payment of $\$ 35.5$ million (in addition to providing substitute collateral that virtually eliminated any chance of default) by threatening specific enforcement of the collateral provisions. ${ }^{18}$ Examples abound in which the plaintiffs seek inefficient injunctive relief in order to extract a premium above the value of actual performance. ${ }^{19}$

${ }^{15}$ Id. (emphasis added).

${ }^{16}$ EDWARD YORIO, CONTRACT ENFORCEMENT: SPECIFIC PERFORMANCE AND INJUNCTIONS 85 (1989).

${ }^{17}$ Rieuman, 118 F.R.D. at 30.

${ }^{18}$ See id. at 33 ("The bondholders' lien ... permits [bondholders] to insist on receiving the 'hold-up' premium to which that lien has given rise."). The court, however, also refused to allow a minority of bondholders to extract even more money from the defendant by objecting to the $\$ 35$ million premium. $I d$.

${ }^{19}$ See, e.g., Northern Ind. Pub. Serv. Co. v. Carbon County Coal Co., 799 F.2d 265, 279 (7th Cir. 1986) ("Probably, therefore, [the seller] is seeking specific performance in order to have bargaining leverage with [the buyer] ...."); Foster v. American Mach. \& Foundry Co., 492 F.2d 1317, 1324 (2d Cir. 1974) (stating that an injunction prohibiting infringement "is not intended as a club to be wielded by a patentee to enhance his negotiating stance"); Bracewell v. Appleby, [1975] Ch. 408, 416 (refusing to grant an injunction that would prohibit the defendant from occupying his own house because an in part injunction would place plaintiffs in "an unassailable bargaining position"); see also YoRIO, supra note 16, at 83 ("The availability of specific performance or injunctive relief gives the plaintiff considerable leverage in negotiations between the parties.").

Defendants against whom injunctions issue at times pay an amount in settlement instead of performing. For example, in Tulk $v$. Moxhay, Tulk sued to prevent Moxhay from building on Leicester Square garden. 41 Eng. Rep. 1143 (Ch. 1848). Since Tulk's deed had a covenant requiring that the Square be "uncovered with any buildings," the court granted Tulk the injunction. See id. at 1143. The Tulk family ultimately traded its injunctive right in exchange for a valuable option. See JESSE DUKEMINIER \& JAMES E. KRIER, PROPERTY 863 (3d ed. 1993) (explaining the subsequent history of Tulk $v$. Moxhay). 
While these previous examples concern how people who are owed a duty can have an incentive to threaten inefficient performance of injunctions, it is also possible that people who owe a duty will threaten inefficient performance merely to increase their bargaining power. People who owe performance of a duty are likely to threaten inefficient performance whenever expected damages equal or exceed the cost of performance. This can be seen in a contractual setting when a court is expected to award cost of performance damages.

Whenever expected court-awarded damages exceed the promisee's benefit from performance, a promisor's threat to perform may induce the promisee to settle a case for less than the court award. Returning again to a stylized variation of Peevyhouse, imagine now a jurisdiction that would award $\$ 30,000$ as cost of performance damages if the miner breached its promise (to restore the topsoil of the stripmined land), even though the farmer's value of actual performance is only $\$ 8000$. Before performance is due, the promisor might try bargaining her way out of performing by offering to pay the promisee some amount between $\$ 8000$ and $\$ 30,000$, say by splitting the difference at $\$ 19,000$-again, the Nash bargaining solution.

The naive promisee at this point might respond: "Why should I accept $\$ 19,000$ when my contract damages will be $\$ 30,000$ ?" A savvy miner, however, will answer: 'You're mistakenly assuming that I will breach if we don't reach agreement. If we don't renegotiate this contract, you should know that I am going to perform and you will end up with only an $\$ 8000$ benefit."

The promisor gains bargaining power by threatening to perform. Even though the promisor knows performance is inefficient, threatening performance can be an individually rational strategy because it

In a recent, excellent article, Ward Farnsworth found that in twenty recent nuisance cases in which injunctions were issued, the parties failed to negotiate whether a payment would be made in lieu of performance. Ward Farnsworth, Do Parties to Nuisance Cases Bargain After Judgment? A Glimpse Inside the Cathedral, 66 U. CHI. L. REv. 373, 381-83 (1999). Farnsworth argues that acrimony and distaste for bargaining may have deterred such negotiations. See id. at 384 . If the Farnsworth result were generally true, then one might reasonably doubt whether plaintiffs ever seek injunctions in order to extract supercompensatory payments from the defendant. Besides the aforementioned counterexamples such as Edwards, there are strong reasons to question whether one can make a generalization from these twenty observations. Farnsworth only examines appellate decisions. As he acknowledges, the litigants that fail to settle by this point in the litigation might be strongly predisposed toward acrimony and distaste for bargaining. See id. And even to the extent that one can generalize the result, our proposed reforms, by more explicitly stating when an injunction is alienable, may encourage negotiations among litigants who may have otherwise failed to consider negotiation. 
disproportionately hurts the promisee. Moreover, under the assumed facts, the threat is credible because in the absence of agreement actual performance would cost the promisor no more than he would have to pay in damages-indeed, actual performance potentially saves attorney fees.

Inefficient performance threats can produce both ex ante and ex post types of inefficiency. Ex post, a threat of inefficient performance might entail the cost of the negotiations themselves, and the costs resulting when the failure to reach a bargain results in inefficient performance. As Richard Epstein has noted: "Injunctive relief thus poses two major risks: first, that parties will waste enormous resources in bargaining over the surplus and, second, that they will not be able to reach any agreement at all given the tendency to bluff and bluster. ${ }^{{ }^{20}}$ More subtly, the prospect of being threatened ex post may distort ex ante behavior. Thus, in the contract setting, the prospect of both inefficient threats and payoffs that substantially diverge from makewhole damages may adversely affect the parties' original willingness to contract or to rely on the contract.

Inefficient threats are commonplace in bargaining. Jones may resist selling her car to Smith, even though she knows that Smith values it more, merely to induce a higher purchase price. The inefficiency produced by such quotidian threats, however, is greatly reduced by competition. Smith can look for other sellers. The performance threats analyzed in this article are distinguishable because they arise under conditions of bilateral monopoly. ${ }^{21}$ Once a court orders Pedrick to remove the encroaching wall, Pile is the only person to whom Pedrick can look to avoid the performance inefficiency. ${ }^{22}$ Threatening inefficient behavior to induce more favorable contract terms is more worrisome when the parties do not have outside, competitive options. The common law at times, such as in the case of salvage, constrains the parties' ability in bilateral monopoly contexts to make inefficient threats as a way of limiting the potential inefficiencies and inequities of such negotiations. ${ }^{23}$

so RICHARD A. EPSTEIN, CASES AND MATERIALS ON TORTS 714 (6th ed. 1995); see also Ken Binmore et al., Hard Bargains and Lost Opportunities, 108 ECON. J. 1279, 1279 (1998) (finding that experimental subjects with imperfect information often fail to achieve efficient bargaining outcomes).

${ }^{21}$ The unique efficiency problems posed by bilateral monopolies are discussed in Ian Ayres, Monsanto Lecture: Protecting Property With Puts, 32 VAL. U. L. REV. 793 (1998).

${ }_{22}^{22}$ Pedrick is the only person Pile can hold up.

${ }^{23}$ See infra notes $24-25$ (suggesting legal rules which would reduce the parties' use of inefficient threats). 
Under conditions of bilateral monopoly, it is presumptively inefficient for either promisor or promisee to threaten inefficient performance merely to gain renegotiation bargaining power. The law might usefully be structured to deter such threats-even though it does not intervene to regulate negotiations where the bargainers have outside options. Courts, however, will often have difficulty distinguishing efficient from inefficient threats. For example, promisees might seek specific performance because they place a high subjective value on performance rather than a desire to sell their injunction back to the promisor. Our solution is to suggest legal rules that economize on the parties' private information, particularly on the threatened party's knowledge. $^{24}$

We will argue that the law can give the threatened party options to make inefficient threats less attractive. In particular; we assess the efficiency effects of two remedial reforms that undermine the credibility of inefficient threats:

Inalienable Injunction Option: Before asking plaintiffs to elect monetary or injunctive relief, courts could routinely give defendants an option to make any injunctive relief inalienable. Threatened parties would have the option of forgoing their ability to buy their way out of an injunction. By exercising this option, a threatened promisor in effect would be telling the promisee: "Force my performance if you really want my performance, but don't seek an injunction merely to hold me up for money." Under the facts of Pile, making the injunction inalienable might have deterred the plaintiff from seeking the inefficient injunction to have the encroaching wall removed. The plaintiff might have preferred monetary damages (of $\$ 500$ ) to an inalienable injunction that would have provided the plaintiff only a negligible benefit.

Private Additur and Remittitur. Courts could routinely give the

${ }^{24}$ Louis Kaplow and Steven Shavell have shown how liability rules can economize on private information. See Louis Kaplow \& Steven Shavell, Property Rules Versus Liability Rules: An Economic Analysis, 109 HARV. L. REV. 713, 726-27 (1996) ("[U]nder the liability rule, the state is able to make implicit use of injurers' information about prevention costs, because injurers know their actual prevention cost, which they compare to average harm."); see also Ian Ayres \& J.M. Balkin, Legal Entitlements as Auctions: Property Rules, Liability Rules, and Beyond, 106 YALE L.J. 703, 749 (1996) (discussing the advantages of higher order liability rules, including the fact that they harness information efficiently). Our theory suggests that when one side has the option of choosing a property rule negotiation, the other side should be given an offsetting option. 
threatened party the option to commit to "less favorable" monetary damages. Before performance is due, promisees could be given the option to decrease the potential legal damages they would receive in the event of breach. Likewise, before promisees commit to injunctive relief, promisors could be given the option to increase the potential legal damages they would pay in the event of breach. This would amount to a system of private additur and remittitur, in which plaintiffs could choose before trial to reduce the damages they would potentially collect and defendants could choose to increase the damages they would potentially pay. ${ }^{25}$

An extension of the earlier cost of performance strip-mining example shows how these options might work. When a promisor, bargaining in the shadow of $\$ 30,000$ cost of performance damages, inefficiently threatens to perform, the farmer/promisee should have the option of reducing his legal damages to, for example, $\$ 25,000$. While choosing lower legal damages seems superficially "less favorable" for a plaintiff/promisee, doing so can actually benefit the promisee. As long as the promisor can credibly threaten performance, it may be able to buy back its promissory duty for a relatively small amount (say $\$ 19,000)$. By lowering the background damages, the promisee can make the promisor's threat non-credible. The promisor might still claim that he will perform in the absence of renegotiation, but the promisee (having reduced the damages) could now respond, "I don't believe you; when push comes to shove, you will breach and pay me $\$ 25,000$ instead of performing at a cost of $\$ 30,000$." Surprisingly, the promisee can increase its expected payoff by reducing its potential legal damages.

While plaintiff remittitur and defendant additur, combined with injunction inalienability, can both deter threats of inefficient performance, we will argue that there is a stronger case in equity and efficiency for structuring the law to deter plaintiffs' threats of inefficient injunctions. Plaintiffs' threats are likely to drive plaintiffs' payoffs substantially above make-whole damages while defendants' threats are likely to drive plaintiffs' payoffs down closer toward make-whole dam-

${ }^{25}$ A provision in an initial agreement that fixed liquidated damages as the exclusive remedy could obviate the need for the additur and remittitur options. But parties may be reluctant to fix liquidated damages when they cannot anticipate what the amounts should be at the time they enter the contract. As discussed below in Part IV.A, our proposed reforms only constitute default rules that would govern in the absence of a contrary agreement. 
ages. We suggest that courts give defendants the options of injunctive inalienability and additur to deter plaintiffs' efforts to increase payments above expectation damages, but that courts not try to deter defendants' efforts to use performance threats to reduce damages toward the expectation amount.

While it is nigh-on impossible to construct a single damage rule that will induce efficient behavior along all possible dimensions, ${ }^{26}$ giving defendants the options of inalienability and additur leads toward more efficient plaintiff precaution and, under certain conditions, more efficient defendant reliance as well as a possibility of more efficient ex post negotiations. The strongest rationale for injunctive inalienability (and additur), however, is based not on efficiency but on equity. Some injunctions are granted in order to give the plaintiff rights-holder an entitlement to bargain for whatever exchange value the plaintiff can negotiate. Injunctions against patent infringement, for example, are often aimed at giving the patentee the ability to negotiate a high licensing fee. But judges award many, if not most, injunctions merely to provide the plaintiff the "use value" of actual performance." "Use value" injunctions are granted in part because of courts' concerns that monetary damages may not fully compensate the plaintiff. Giving plaintiffs the option to seek alienable injunctions reduces the chance of undercompensation at too high an equitable price by creating the possibility of substantial overcompensation. Giving plaintiffs instead the choice of either an inalienable injunction or damages (possibly enhanced by the defendant) retains the prime benefit of an alienable injunction, the elimination of the threat of undercompensation, by ensuring that plaintiffs can receive in kind the actual performance to which they are entitled. But an inalienable injunction sharply reduces the inequitable risk of overcompensationthat is, the risk that plaintiffs will seek an injunction solely for the pur-

${ }^{26}$ See Steven Shavell, Damage Measures for Breach of Contract, 11 BELLJ. ECON. 466, 488-89 (1980) (concluding that although the use of damage measures is in the mutual interest of both parties to a contract and leads to efficient behavior, factors such as the respective risk aversion of the parties and limited information of the enforcing court can limit the effectiveness of such measures). In a 1985 article, Robert Cooter emphasizes the difficulty of formulating efficient legal rules when efficiency requires bilateral precaution. See Robert Cooter, Unity in Tont, Contract, and Property: The Model of Precaution, 73 CAL. L. REv. 1, 4 (1985) (arguing that, because assigning full responsibility for the injury to one party or parceling it out between the parties cannot fully internalize costs for both of them, there is no level of compensation that achieves double responsibility at the margin).

${ }_{27}$ The distinction between "use value" and "exchange value" is discussed below at notes $114-15$ and accompanying text. 
pose of receiving a payment far greater than the amount that they actually value performance.

Common law courts already respond to the problem of plaintiffs threatening inefficient performance by denying injunctions that impose disproportionate hardship on the defendant in comparison to the benefit that the plaintiff would derive from performance of the injunction. ${ }^{28}$ We support these decisions. Often, however, courts with imperfect information or courts worried about the possibility of plaintiff undercompensation grant an injunction where the defendant's burden outweighs the plaintiff's benefit. Courts should accordingly go beyond the decisions judiciously denying injunctions; they should consider regulating plaintiffs' ability to hold up defendants for supercompensatory amounts.

Our defendant additur and inalienability options rely on the game-theoretic prediction that such defendant options can deter plaintiffs from initially seeking injunctions. A problem with such reforms is that if they do not succeed in deterring plaintiffs, they can lead toward even more inefficient performance. As an alternative, we suggest that judges consider subjecting all injunctive settlements to the same type of remittitur analysis to which a jury award would be subjected. A remittitur review of injunctive settlements-that is settlements whereby defendants agree to pay plaintiffs in lieu of performance-would amount to an ex post judicial cap on how much plaintiffs could gain from an injunction. Such a review might achieve some of the deterrence effects of inalienability, without seeming like such a radical departure from current procedure and without creating as great a risk of inefficient performance. Any of our proposed reforms-judicial remittitur, inalienability, or defendant additurshould be thought of as default rules that the parties could disclaim in an initial contract or that defendants could disclaim at an early stage in the litigation before the plaintiff elects monetary or injunctive relief.

This Article is divided into four sections. The first section explores the conditions under which people who are owed duties and people who owe duties will threaten inefficient performance. The second section shows how the inalienable injunction and private remittitur and additur options will deter such threats by undermining their credibility. The third section assesses the ex ante and ex post efficiency effects of threats to perform and of our proposals to stop

${ }^{28}$ See infra notes 45-46 and accompanying text (addressing the common law undue burden rules that courts use to deny injunctive relief in certain situations). 
them. The final section discusses more specific means by which courts may limit threats to perform.

\section{A UNIFYING THEORY OF PERFORMANCE THREATS}

This section presents a simple model to show (1) when someone who owes or is owed a duty will desire to threaten inefficient performance and (2) when such a threat will be credible. In this model, imagine that a potential defendant owes some duty of performance to a potential plaintiff. ${ }^{29}$ The duty might be contractual in nature (as in the Peecyhouse duty to return topsoil) or non-contractual in nature (as in the Pile duty to remove an encroaching wall). Assume that:

$$
\begin{aligned}
& C=\text { the defendant's cost of performance; and } \\
& B=\text { the plaintiff's benefit from performance. }
\end{aligned}
$$

Because we are interested in exploring threats when performance is inefficient, we also assume that at the time performance is due $\mathrm{C}>$ $\mathrm{B}^{30}$ If either side credibly threatens performance (as formally defined below), the parties will negotiate to avoid the inefficiency-specifically, the defendant will offer to pay the plaintiff to release the defendant from her performance duty. When the parties have asymmetric information about $B$ and $C$, this negotiation can produce inefficient results. For now, we assume $\mathrm{B}$ and $\mathrm{C}$ are common knowledge between the players and negotiation costs are nil so that the players expect negotiations to succeed. We also assume the expected negotiated amount the defendant pays for the plaintiff's release in the shadow of a credible performance threat is:

$\mathrm{N}=\alpha \mathrm{C}+(1-\alpha) \mathrm{B}$, where $\alpha \sim[0,1]$ is a measure of plaintiff's bargaining power.

$\mathrm{C}$ and B are the players' "threat points" or "BATNAs" (best alternative to negotiated agreement) once performance has been credibly threatened. The negotiated amount, $N$, falls somewhere between these threat points depending on the parties' relative bargaining

${ }^{29}$ By flip of a coin, we have decided to refer to the plaintiffs and the defendants by male and female pronouns respectively.

${ }^{30}$ Even though contractors would not enter into a contract expecting $C$ to be greater than B, after a contract is formed, $C$ may turn out to be higher than expected (or B may turn out to be lower than expected). 
power, which for convenience, we have reduced to the scalar, $\alpha^{31}$

Finally, we assume that if the defendant fails to perform, the plaintiff can seek either specific performance or monetary damages equal to:

$\mathrm{D}=$ expected monetary damages if the defendant fails to perform (and if plaintiff does not seek specific performance).

We will consider the players' incentives under a range of different damage levels-including subcompensatory $(D<B)$, compensatory $(D=B)$, supercompensatory $(D>B)$, and a special subcategory of supercompensatory, cost of performance $(D=G)$.

Two conditions must be present before performance threats will generate bargaining. First, one of the parties must desire to threaten performance (motive), and second, that party must be able to make a credible threat (opportunity).

\section{A. The Motive to Threaten Inefficient Performance}

The relationship between the level of damages (D) and the expected payoff from negotiation $(\mathrm{N})$ will determine which side has an incentive to make a threat. The motive to threaten inefficient performance is the motive to supplant the damage award with a more favorable negotiated amount. More specifically:

- If $\mathrm{D}<\mathrm{N}$, the plaintiff will want to threaten inefficient performance to increase his expected payment; and

- If $\mathrm{D}>\mathrm{N}$, the defendant will want to threaten inefficient performance to decrease her expected payment.

These inequalities suggest that one side or the other will often have a desire to threaten inefficient performance in order to supplant the expected award of damages. Damages are usually set to approximate $B$ in order to make the plaintiff whole, or alternatively set to ap-

st Bargaining power might turn on a host of bargaining primitives, including procedure (take-it-or-leave-it vs. alternating offers, etc.), the players' relative impatience, the cost of bargaining, and even the hopes of the parties involved. See Jennifer Gerarda Brown, The Role of Hope in Negotiation, 44 UCLA L. REV. 1661, 1669 (1997) (arguing that hope acts as an independent, primitive variable upon which negotiation behavior depends). 
proximate $\mathrm{C}$ (as with cost of performance or restitutionary awards). ${ }^{32}$ When the parties bargain in the shadow of a performance threat, however, the negotiated amount, $\mathrm{N}$, will systematically be between $\mathrm{B}$ and $C$. The larger the inefficiency (i.e., the more $C$ exceeds $B$ ), the larger the likelihood that one side or the other will have a strong incentive to change the expected payment from $D$ to $N$. Thus, in our earlier encroachment example, when legal damages were set to approximate $B$, the plaintiff had a strong incentive to seek an injunction to threaten inefficient performance and the likely negotiation it in turn would produce. In our cost of performance example, where damages were set to approximate $\mathrm{C}$, the promisor had a strong incentive to threaten inefficient performance to reduce her ultimate payment. In a richer model, the costs of renegotiation and the costs of failed negotiation could dampen the parties' desire to make such threats, but perversely, the more inefficient performance becomes, the larger the chance that at least one party will have a desire to threaten inefficient performance.

\section{B. When Will a Potential Defendant's Performance Threat Be Credible?}

Motive, however, does not connote opportunity. Only credible threats of inefficient performance will spur negotiation. If the threatened party has no reason to believe the threatener will carry out the threat to perform, he has no reason to bargain. This credibility problem particularly restricts the ability of potential defendants to threaten inefficient performance. The opportunity for defendants to threaten performance arises when, before performance is due, ${ }^{33}$ potential de-

${ }^{32}$ Cost of performance damages can approximate expectation damages under the assumption that the plaintiff will use the damage amount to purchase performance and thereby put himself in the same position as if the defendant had performed. See Steven J. Burton, More on Good Faith Performance of a Contract: A Reply to Professor Summers, 69 IOWA L. REv. 497, 506 (1984). When changed circumstances cause the defendant's cost of performance to radically exceed the plaintiff's benefit, however, then the plaintiff is unlikely to use the cost of performance damages amount received to buy substitute performance-so that cost of performance puts the plaintiff in a better circumstance than actual performance.

${ }^{33}$ After performance is due, a promisor cannot credibly threaten to perform (unless the promisor has a right to cure, see U.C.C. $\$ 2-508$ (1989)). More generally, a person owing some non-contractual duty to another cannot threaten inefficient performance if there is not sufficient opportunity to contract for payment instead of performance. Imagine, for example, a stylized version of Hewlett in which a court imposed a tort duty of care on barge operators to carry a particular radio in case of an 
fendants threaten to actually perform their promise or noncontractual duty-instead of failing to perform and being held liable for damages (D). The potential defendant implicitly threatens the plaintiff: "Let me pay you $\mathrm{N}$ instead of $\mathrm{D}$ or else I will perform and you'll only have a benefit of B." This threat is only credible, however, if the plaintiff believes that if he refuses the offer, the defendant will actually perform. In the simple model, the defendant's threat will be credible only if:

$$
\mathrm{D}>\mathrm{C} \text {. }
$$

When expected damages equal or exceed the defendant's expected cost of performance, the defendant will be able to credibly threaten performance in the absence of renegotiation because carrying through on the threat costs the defendant the same as or less than paying damages.

While legal damages often focus on making the plaintiff whole, in a variety of contexts courts instead invoke a "disgorgement" principle that attempts to put the defendant in the same position as if she had performed her duty. ${ }^{34}$ One particular form of disgorgement remedy, cost of performance damages, can often give potential defendants the ability to make a credible performance threat. If cost of performance damages equal the defendant's actual cost of performance, the defendant loses nothing by carrying out her threatened performance in the event that negotiations fail.

Commentators have correctly noted that cost of performance damages and other extraordinary damages that place the defendant

emergency. See Hewlett v. Barge Bertie, 418 F.2d 654 (4th Cir. 1969). If the performance of this duty is inefficient (meaning the cost of performance is greater than the benefit of reduced accident costs), then we might imagine barge owners threatening to perform the duty unless the class of beneficiaries (potential accident victims) agreed to indemnify the barge owners for any tort liability stemming from failure to take this type of care. But the class of potential signatories is so vast that there is not a practicable opportunity to contract-and therefore no opportunity to threaten.

${ }^{34}$ See E. Allan Farnsworth, Your Loss or My Gain? The Dilemma of the Disgorgement Principle in Breach of Conlract, 94 YALE L.J. 1339, 1354-69 (1985) (discussing judicial use of the disgorgement principle in cases "involving fiduciaries, sellers of goods who would be liable in conversion, and sellers of land ${ }^{n}$ ). Courts often struggle with the issue of whether to give cost of performance or cost of repair damages when such damages would greatly exceed a "diminution in value" measure. See, e.g., Heninger v. Dunn, 162 Cal. Rptr. 104, 106-09 (1980) (explaining the use of the dimunition of value and restoration damages where replacement costs are unreasonable); Jacob \&Youngs, Inc. v. Kent, 129 N.E. 889, 891 (N.Y. 1921) (Cardozo, J.) (arguing the merits of diminution of value versus cost of completion remedies in a breach of contract case where "the cost of completion is grossly and unfairly out of proportion to the good to be attained"). 
in the position of performance are (like specific performance) a species of what Calabresi and Melamed called "property rules," which tend to deter defendants from non-consensual takings. ${ }^{35}$ Avery Katz has called such damages "liquidated specific performance," arguing that such remedies give the plaintiff all of the gains from efficient breach. ${ }^{36}$ But the foregoing shows that cost of performance and other disgorgement damages may not result in giving the plaintiff all of the gains from performance. By allowing the defendant to credibly threaten inefficient performance, disgorgement remedies may allow the defendant to bargain to pay substantially less.

What happens when damages are less than the defendant's cost of performance $(D<C)$ ? It would at first seem that the promisor's threat to perform would lose its credibility. The validity of this conclusion, however, hinges on the divisibility of the defendant's performance. In a 1996 article, Lucian Bebchuk showed that plaintiffs who expect to spend more litigating than they would gain from winning a suit might still have a credible threat to sue if the litigation costs are incurred in stages over time. ${ }^{37}$ Bebchuk's insight can be applied in the bargaining context where the anticipated damage award is less than the cost of performance. If the defendant's performance is due in discrete stages, it may be credible for the defendant to threaten performance even though the total cost of performance is greater than the expected damages. For example, assume that the total cost of performance is 30 , but that it is broken up into two discrete stages each costing 15. Assume also that the plaintiff's benefit (B) is 8 , that expected damages (D) are 27, and that the parties have equal bargaining power and an opportunity to bargain before each stage of

35 See generally David D. Haddock et al., An Ordinary Economic Rationale for Extraordinary Legal Sanctions, 78 CAL. L. REV. 1 (1990) (developing a property analysis of the role of extraordinary legal sanctions in an efficient legal system and extending the model to explain various seemingly illogical and disjointed tort and contract damage rules).

${ }^{36}$ Avery Katz, Reflection on Fuller and Perdue's The Reliance Interest in Contract Damages: A Positive Economic Framework, 21 U. MICH. J.L. REFORM 541, 547 (1988).

${ }^{37}$ See Lucian Arye Bebchuk, A New Theory Concerning the Credibility and Success of Threats to Sue, 25 J. LEGAI STUD. I (1996) (utilizing backward induction to explain why defendants can expect to settle negative value suits due to the divisibility of litigation costs). When litigation costs are divisible, the costs incurred in the last stage may be less than the damage award, making a threat to sue credible at that stage. If the parties reach this stage, they will expect to settle. The plaintiff will of course take this anticipated last-stage settlement into consideration when he decides whether to embark on the next-to-last stage. If his payoff from this last-stage settlement is greater than his next-to-last stage litigation costs, then he has reason to initiate a suit. In other words, his litigation threat is credible. 
performance. Then it is possible to show-à la Bebchuk-that the defendant can credibly threaten performance. Even though the total cost of performing (30) is more than the defendants expect to pay in legal damages (27), the division of performance over time makes the threat credible. It can be shown that if the parties have equal bargaining power in equilibrium, the defendant should only expect to pay the plaintiff 17.25 to release herself from her duty, an amount substantially less than either damages or cost of performance. ${ }^{38}$ The defendant's threat to perform will be credible for any fixed damage amount greater than 26.5. This example shows then that performing over time can increase the defendant's ability to make credible threats of inefficient performance. ${ }^{39}$

The size of $D$ is crucial to determining whether the defendant's threat to perform is credible, but if the performance threat is credible the damages have no independent impact on the expected settlement. A core result of non-cooperative bargaining theory is that the negotiated amount will be a function of the parties' threat points. If

ss Breaking performance into two stages makes the defendant's performance threat credible. In the last stage, the defendant will actually prefer to perform (since she will spend 15 rather than pay damages of 27). Since her performance threat at this last stage is credible, the parties would agree to settle at this stage (if they ever reached this stage) for 11.5 (the midpoint solution between the plaintiff's benefit of 8 and the seller's non-sunk prospective costs of 15 ). Anticipating this negotiation at the last stage, the defendant prefers to expend 15 at the first stage, since $15+11.5=26.5$ is less than damages at 27 . But given that the staged costs make full performance credible from the beginning, both parties prefer to negotiate immediately, settling on a payment midway between the parties' threat points: a $(8+.5(26.5-8))=17.25$ payment by the defendant to the plaintiff.

${ }^{39}$ There is, however, a caveat concerning this analogy to Bebchuk's litigation cost model. In the litigation cost model, expenditures on suit preparation are assumed not to be correlated with the amount of damages that would be awarded in the suit. In other words, a non-credible threat becomes credible since the division into stages makes the litigation costs the party has yet to incur drop, while the suit damages remain constant. In contrast, damages awarded in a breach of contract suit may be a function of the performance that has occurred. For example, a painter paints the bottom floor of a house, but announces that he will breach the contract before completing the second floor of the house. The cost of painting the first floor will likely be deducted from the damages that would have been awarded had the contract been breached before any performance. If the level of damages and the cost of performance decrease by exactly the same amount, the threat will remain non-credible. For this reason, if partial performance reduces the expected damage award (D), then the plaintiff's performance threat will only be credible where the adjusted damage award is proportionally larger than $\mathrm{D}$. This might happen if the court believes it is difficult for a second contractor to pick up where the first contractor left off. Contracts involving some sort of learning curve would be one example. In this case, the cost of completion damage award would necessarily be greater than the original promisor's remaining cost of performance. 
the defendant can credibly threaten performance, then the relevant payoffs in the absence of agreement become B and C. The level of damages should play no role in determining the size of the negotiated amount $(\mathrm{N})$ other than ensuring credibility because, in the shadow of a credible performance threat, there are no circumstances under which the defendant will ever have to pay court-awarded damages.

Focusing on the defendant's ability to make credible threats also illuminates an interesting distinction between cases of "impossibility" and "impracticability." Defendant threats are not credible when performance itself is literally impossible. A defendant facing cost of performance damages, however, can credibly threaten performance when performance is possible but merely impracticable (i.e., extremely costly). The law, at times, responds to evidence of either impracticability or unconscionability by reducing the defendant's expected damages. This is primarily accomplished by using the diminution in value damage measure instead of a cost of performance measure ${ }^{40}$ (and more rarely by voiding the defendant's duty to perform altogether, effectively reducing the defendant's damages for nonperformance to $\$ 0){ }^{41}$ If lawmakers wish to deter defendant threats, ${ }^{42}$ there is a stronger case for reducing the defendant's damages when the defendant's performance is merely impracticable not impossible. Reducing damages substantially below the cost of performance when performance is impracticable can render the defendant's threats non-credible. When the defendant's performance is impossible, however, it is not necessary to reduce the defendant's liability to deter performance threats. The defendant can not credibly threaten to do the impossible. Thus, while we normally think that evidence of impossibility provides a stronger rationale for relief than mere impracticability, from the standpoint of deterring the defendant's threats of performance, the opposite is true.

\section{When Will a Plaintiff's Performance Threat Be Credible?}

Plaintiffs threaten to cause defendants' performance by seeking injunctive orders of performance. The major obstacles in making this threat are equitable rules limiting the award of this "extraordinary"

${ }^{40}$ See Jacob \& Youngs, Inc. v. Kent, 129 N.E. 889, 891 (N.Y. 1921) (awarding diminution in value damages where cost of performance damages were excessive).

${ }^{41}$ See U.C.C. $\$ 2-615$ (1997) (discussing when breach of contract due to the impracticability of performance does not constitute a breach of duty).

${ }^{42}$ Ultimately we will argue they should not. See discussion infra Part III. 
remedy. The primary limitation, as traditionally formulated, is that injunctions will only be granted to prevent an irreparable injury (or as equivalently formulated, if there is no "adequate legal remedy"). ${ }^{43} \mathrm{But}$ Douglas Laycock has shown as a matter of positive U.S. law that "[ $t]$ he irreparable injury rule almost never bars specific relief" and an emerging consensus is that courts routinely give plaintiffs an option for specific relief in a far wider range of contexts than previously thought. ${ }^{44}$

Under a variety of doctrines, however, courts will still deny injunctive relief that imposes undue hardship on a defendant (in comparison to the benefit that the plaintiff will derive from the injunction)..$^{45}$ These undue burden limitations make good economic sense because they limit the ability of plaintiffs to threaten inefficient performance when their motive to do so is the strongest. The essence of the "undue burden" rules is to identify circumstances where the defendant's cost of performing some duty (C) far exceeds the plaintiff's benefit of performance (B). ${ }^{46}$ It is in just these circumstances that the amount expected from negotiating away an injunction (N) is likely to far exceed what the plaintiff might receive in court-awarded damages, and that plaintiffs will therefore have an incentive to seek the injunction as a bargaining chip. ${ }^{47}$ The refusal of courts to issue injunctions that

${ }^{43}$ See, e.g., United States v. American Friends Serv. Comm., 419 U.S. 7, 11 (1974) (examining the prerequisites for issuance of an injunction).

${ }^{4}$ DOUGLAS LAYCOCK, THE DEATH OF THE IRREPARABLE INJURY RULE 23 (1991).

${ }^{45}$ See RESTATEMENT (SECOND) OF TORTS \$ 826(a) (1977) (intentional nuisance should be enjoined as unreasonable only if "gravity of the harm outweighs the utility of the actor's conduct"); YORIO, supra note 16, at 41 ("For specific performance to be proper, however, the marginal benefit to the promisee must be sufficiently great that it outweighs the marginal costs imposed on the promisor and on the legal system." ); see also DOUGLAS LAYCOCK, MODERN AMERICAN REMEDIES: CASES AND MATERIALS 219 (1985) ("One of the grounds for vacating a final judgment of injunction is that the injunction is causing undue hardship to defendant ....").

${ }^{46}$ See RESTATEMENT (SECOND) OF CONTRACTS $\$ 364(1)$ (b) (1979) (discussing when injunctive relief is inappropriate due to unreasonable hardship to the party in breach); YORIO, supra note 16, at 110 ("[T] he issue of equitable relief is viewed often in terms of a balancing test, with specific performance denied if the burden on the defendant from enforcement of the contract would exceed the benefit to the plaintiff."); see, e.g., Ben Simon's, Inc. v. Lincoln Joint-Venture, 535 N.W.2d 712, 715 (Neb. 1995) (refusing to issue an injunction to tear down restaurant built in violation of lease because benefit to plaintiff was greatly exceeded by burden on defendant).

${ }^{47}$ The classic illustration of this is Boomer v. Atlantic Cement Co., Inc., 257 N.E.2d 870,872 (N.Y. 1970) ("The total damage to plaintiff's properties is, however, relatively small in comparison with the value of defendant's operation and with the consequences of the injunction which plaintiffs seek."). As parsed recently by Judge Posner:

The defendant's factory was emitting cement dust that caused the plaintiffs harm monetized at less than $\$ 200,000$, and the only way to abate the harm would have been to close down the factory, which had cost $\$ 45$ million to 
would impose an undue hardship on defendants has "the effect of preventing the plaintiff from using an equitable remedy to extort an overcompensatory settlement." ${ }^{n 8}$ The possibility of such equitable defenses accordingly undermines the credibility of plaintiffs' performance threats. A court's refusal to grant an injunction on such equitable grounds, however, also increases the chance plaintiffs will be undercompensated by monetary damages.

Because of this risk of undercompensation, courts at times do grant injunctions when defendant's injunctive burden (C) is substantially greater than plaintiff's benefit (B). Courts often have difficulty assessing the true costs and benefits of injunctive performance and thus may be unable to determine whether performance would be inefficient. Even when courts believe that performing an injunction would be inefficient, their worry that damages would be inadequate (i.e., would undercompensate a plaintiff) may cause them to issue an injunction as an equitable matter. ${ }^{49}$ Courts might be especially concerned that, because juries decide the awards, the risk of undercompensation is unavoidable.

When courts do give plaintiffs the choice of monetary or injunctive relief, plaintiffs can credibly threaten to seek injunctive performance. It might seem at first that plaintiffs could not credibly threaten to seek an injunction when they would benefit less from injunctive performance than from expected damages $(B<D)$. After all, defen-

build. An injunction against the nuisance could therefore have created a huge bargaining range (could, not would, because it is unclear what the current value of the factory was) .... If the market value of the factory was actually $\$ 45$ million, the plaintiffs would be tempted to hold out for a price to dissolve the injunction in the tens of millions....

Walgreen Co. v. Sara Creek Property Co., 966 F.2d 273, 278 (7th Cir. 1992).

YORIO, supra note 16 , at 84.

${ }^{49}$ Whalen v. Union Bag \& Paper Co., 101 N.E. 805 (N.Y. 1913), provides an extreme example of some courts' willingness to issue injunctions where the cost to the defendant far exceeds the plaintiff's benefit. In the Union Bag case (discussed later in Boomer, 257 N.E.2d at 872 ) the plaintiff's harm was assessed at $\$ 100$ per year while the cost of complying with the injunction was the permanent closing of a mill representing an investment of more than $\$ 1,000,000$. See 101 N.E. at 805 . The New York Court of Appeals concluded: "Although the damage to the plaintiff may be slight as compared with the defendant's expense of abating the condition, that is not a good reason for refusing an injunction." Id. at 806. See Part I.D below, for a discussion of the use of injunctions when there is a concern about undercompensation. See also Part II.B for a discussion of how a legal regime involving private additur may reduce the probability of undercompensation. Anthony Kronman has argued that the "uniqueness" test helps to identify those cases in which a court cannot obtain, at reasonable cost, enough information to permit it to award damages without imposing an unacceptably high risk of undercompensation on the injured promisee. Anthony T. Kronman, Specific Performance, 45 U. CHI. L. REV. 351, 359-63 (1978). 
dants have an analogous trouble threatening performance when the cost of performance is greater than the cost of damages $(C>D)$. This analogy fails because, unlike defendants, plaintiffs have the ability to commit to performance in the absence of a successful negotiation. The structure of civil litigation gives plaintiffs the ability to make such a pre-negotiation commitment. There is almost always a period of time between the plaintiff's election of an injunctive remedy and the defendant's actual performance. Since the defendant will be willing to pay $\mathrm{N}$ once the plaintiff has sought an injunction, it becomes credible for a plaintiff to seek the injunction-even if $B<D$.

Figure 1 is a simple game-tree example showing why a plaintiff can credibly seek an inefficient injunction, even when the plaintiff's benefit from receiving actual performance is less than his expected damages. In this example, we assume that the defendant's performance of some duty is inefficient ( $B=0<C=30$ ). Expected legal damages are supercompensatory $(D=1>B=0)$, but less than the expected negotiated payment that would result if the plaintiff could credibly threaten to cause performance ( $D=1<N=15$ ). We also assume the parties negotiate initially, and that the plaintiff then sues for either an injunction or monetary damages. If the plaintiff elects an injunction, the parties have an opportunity to negotiate again. The circles in the figure identify the decision makers at each stage of the game, and the brackets show the monetary payoffs (for the plaintiff and defendant, respectively) for each potential sequence of decisions.

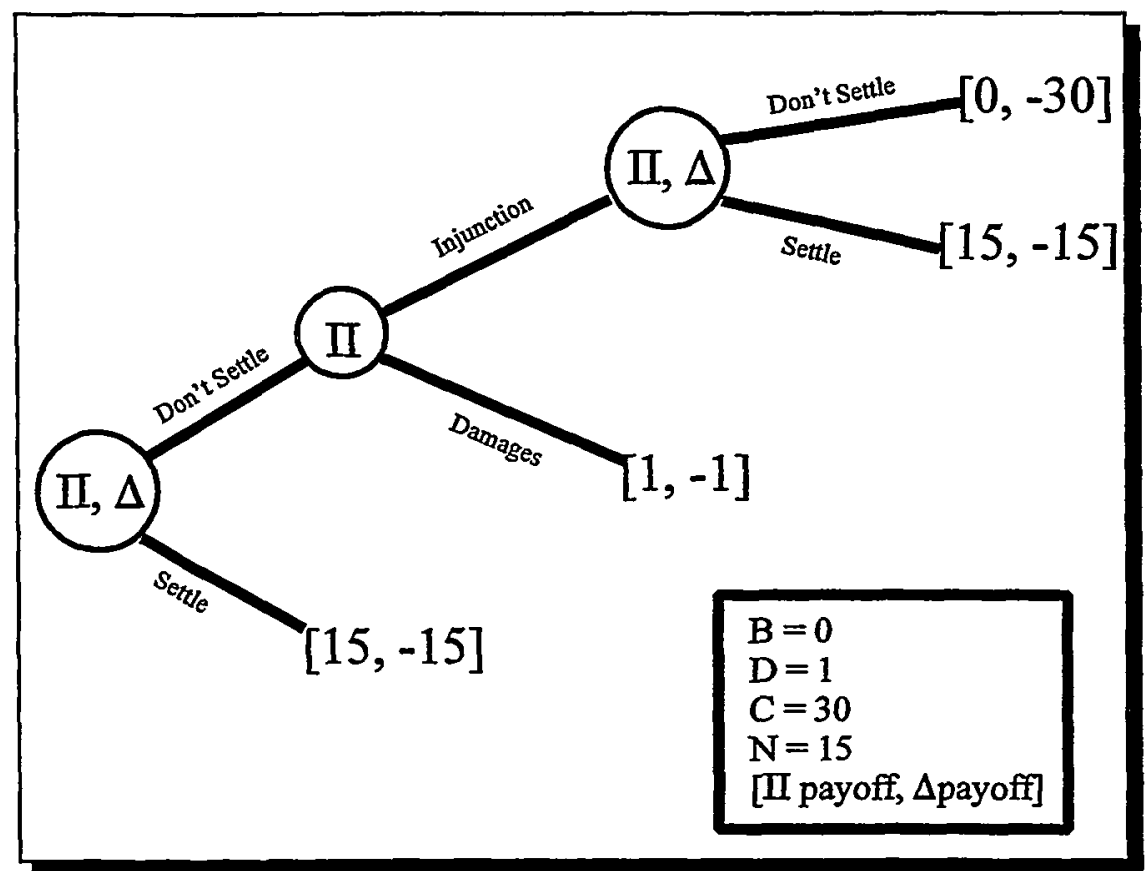


Solving backward, it is easy to see that if the parties reach the final negotiation node, both will prefer to settle (i.e., to agree to dissolve the injunction against the defendant in exchange for payment of 15 to the plaintiff). Foreseeing this outcome, the plaintiff will strongly prefer an injunction (with a 15 payoff) to monetary damages (with a 1 payoff). Finally, because both parties can foresee that the plaintiff will elect injunctive relief, they are likely to settle immediately for $\mathrm{N}=15$ (especially if litigation costs are positive).

D. When Do Performance Threats Cause Payoffs to Diverge From MakeWhole Compensation?

Restricting our attention to the situation in which performance is inefficient (so that $B<N<C$ ), damages can fall into one of four relevant damage ranges as depicted in Figure 2:

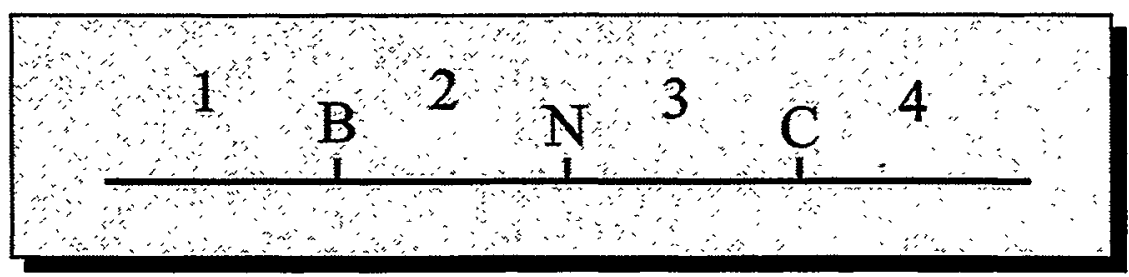

Figure 2: Four Possible Expected Damage Ranges When Performance Is Inefficient 
Table 1 summarizes much of the foregoing discussion in terms of these four damage ranges.

\begin{tabular}{|l|c|c|c|}
\hline Damage Level & $\begin{array}{c}\text { Whose Motive } \\
\text { To Threaten }\end{array}$ & $\begin{array}{c}\text { Is the Threat } \\
\text { Credible? }\end{array}$ & $\begin{array}{c}\text { Expected } \\
\text { Payment }\end{array}$ \\
\hline 1. $\mathrm{D}<\mathrm{B}<\mathrm{N}<\mathrm{C}$ & Plaintiff & Yes & $\mathrm{N}$ \\
\hline 2. $\mathrm{B}<\mathrm{D}<\mathrm{N}<\mathrm{C}$ & Plaintiff & Yes & $\mathrm{N}$ \\
\hline 3. $\mathrm{B}<\mathrm{N}<\mathrm{D}<\mathrm{C}$ & Defendant & $\mathrm{No}^{50}$ & $\mathrm{D}$ \\
\hline 4. $\mathrm{B}<\mathrm{N}<\mathrm{C}<\mathrm{D}$ & Defendant & Yes & $\mathrm{N}$ \\
\hline
\end{tabular}

\section{Table 1: Credible Threats in Four Potential Damage Ranges}

When expected damages are in Ranges 1 or 2, the plaintiff will want to seek injunctive relief to increase his expected payoff from $D$ to $\mathrm{N}^{51}$ As long as the court is willing to issue an injunction in this type of case (for example, where there is no finding of an undue burden on the defendant), the plaintiff's threat to seek an injunction will be credible and the parties will try to negotiate a payment of $\mathrm{N}$ to avoid the inefficiency.

The possibility that court-awarded damages will fail to make the plaintiff whole (Range 1) is one of the primary justifications for granting injunctions. ${ }^{52}$ Judge Richard Posner in particular has criticized the inaccuracy of court-awarded damages relative to negotiated outcomes in the shadow of an impending injunction: "A battle of experts is a less reliable method of determining the actual cost to [plaintiff] of [not receiving defendant's performance] than negotiations between [plaintiff] and [defendant] over the price at which [plaintiff] would feel adequately compensated for [not receiving performance]. ${ }^{.53}$ Once we appreciate the possibility of threatening inefficient performance, however, we see that the payment negotiated in an injunctive

${ }^{50}$ The threat may be credible, however, if costs are incurred in stages as in the Bebchuk model. In this case, the expected payment would be $\mathrm{N}$ as well. See Bebchuk, supra note 37, at 29 (stating that when costs are incurred over time, a plaintiff's otherwise noncredible threat to sue may become credible).

${ }^{51}$ Of course, if the defendant's performance creates no benefit for the plaintiff, then Range 1 will be a null set-i.e., there is no possibility that damages will be less than the plaintiff's benefit.

${ }^{52}$ See Miller v. LeSea Broad., Inc., 87 F.3d 224, 230 (7th Cir. 1996) (noting that damages may be "an inadequate remedy... because of the defendant's lack of solvency or because of the difficulty of quantifying the injury to the victim of the breach").

${ }^{53}$ Walgreen Co. v. Sara Creek Property Co., 966 F.2d 273, 276 (7th Cir. 1992). 
shadow can sharply diverge from make-whole damages. Injunctions not only generate negotiation costs but also introduce inaccuracies of their own. Damages may over- or undercompensate, but injunctions create the risk of substantial overcompensation, and this risk grows when the bargaining range grows. When the inefficiency of performance creates a huge bargaining range, damages may better approximate true make-whole relief than negotiations in the shadow of a credible performance threat. ${ }^{54}$

In Range 2, the threat of inefficient performance unambiguously moves the plaintiff's payoff further away from make-whole relief. Expected damages are already above the make-whole level and threatening inefficient performance only exacerbates the problem $(B<D<$ $N$ ). In Range 1, by contrast, inefficient performance threats substitute a supercompensatory payment $(\mathrm{N}>\mathrm{B}$ ) for subcompensatory damages $(\mathrm{D}<\mathrm{B})$. In both ranges, as the difference between the defendant's cost and the plaintiff's benefit grows, it becomes likely that the negotiated payment (which must fall between these two amounts) will deviate more from make-whole relief than even speculative damages. Giving plaintiffs the option of injunctive relief thus can give plaintiffs the opportunity to raise damages substantially above the break-even level.

In damage ranges 3 and 4 , it is the defendant's turn to threaten performance, in the hope of reducing her expected payment from $D$ to $\mathrm{N}^{55}$ This threat clearly will be credible in Range 4 because the cost of following through on the performance threat is less than the cost of paying damages. However, in Range 3, the performance threat will not be credible unless divisible performance extends a potential de-

${ }^{54}$ Judge Posner sees the primary costs of damage remedies to be the costs of court determination and the costs of inaccuracy, while he sees the primary costs of injunctive relief to be the private "bilateral monopoly" cost of determining the payment:

[When an inefficient injunction creates a large bargaining range,] both parties will have an incentive to devote substantial resources of time and money to the negotiation process. The process may even break down, if one or both parties wants to create for future use a reputation as a hard bargainer; and if it does break down, the injunction will have brought about an inefficient result. All these are in one form or another costs of the injunctive process that can be avoided by substituting damages.

Id. at 276. Both injunctive and damage remedies can produce determination costs and inaccuracies. It is important to recognize that negotiating in the shadow of performance threats does not necessarily produce outcomes that more accurately approximate make-whole damages than court-determined awards.

${ }^{55}$ For ease of exposition, Table 1 ignores the case when expected damages equal B or $\mathrm{N}$ or $\mathrm{C}$. $\mathrm{D}=\mathrm{B}$ will generate the same result as Range $1 ; \mathrm{D}=\mathrm{N}$ will make each side indifferent to threatening inefficient performance; $D=C$ will generate the same result as Range 4. 
fendant's ability to threaten along the lines of the Bebchukian argument discussed above. ${ }^{55}$

Performance threats by defendants, unlike performance threats by plaintiffs, move the plaintiff's expected payoff unambiguously toward make-whole relief. Potential defendants threaten performance when expected court-awarded damages exceed the expected settlement with the plaintiff, which must itself exceed the plaintiff's benefit of performance $(D>N>B$ ). While plaintiff threats tend to cause the plaintiff's payoffs to exceed make-whole relief, defendant threats (if successful in producing a negotiated settlement) cause the plaintiff's payoff to approximate more closely make-whole relief. This distinction will play an important role in Part III when we analyze its implications for choosing efficient legal rules.

\section{HARNESSING PRIVATE INFORMATION TO DISCREDIT PERFORMANCE THREATS}

This section describes how the law might be changed to undermine the credibility of performance threats. The basic approach is to give the threatened party a countervailing option which makes actually carrying through on the threat unprofitable for the threatener. We begin by showing how allowing defendants to make injunctions inalienable can deter some plaintiff threats (in Range 1). By inalienable, we mean only that the defendant cannot pay the plaintiff to release the defendant from her duty to perform the injunction. ${ }^{57}$ Inalienability simply prohibits defendants from paying plaintiffs in lieu of

56 See supra text accompanying notes $37-39$.

57 There is currently a strong consensus that defendants can freely negotiate to discharge their injunctive duties. See DUKEMINIER \& KRIER, supra note 19, at 863 ("It is said that 'an injunction is for sale,' meaning the person who holds it may sell it to the enjoined party if the price is right"). Some courts have even held that the Federal Rules of Civil Procedure do not give them power to restrict the ability of disputants to settle, instead of perform, an injunction. See Smith v. Phillips, 881 F.2d 902, 904 (10th Cir. 1989) (holding that the parties have a "right to unconditional dismissal under Rule 41(a) (1) (ii)"); Wheeler v. American Home Prods. Corp., 582 F.2d 891, 896 (5th Cir. 1977) ("The only provision [in the Federal Rules of Civil Procedure] for approval of a settlement is that for dismissal or compromise of a class action ...."). For a further discussion of inalienable injunctions, see Ayres \& Siegelman, supra note 9. Still, there is no compelling equitable or efficiency reason why judges, in tailoring the scope of an equitable remedy, should not be able to restrict the alienability of injunctions. At least one case seems to imply that a permanent injunction, once issued, would be inalienable. See Rievman v. Burlington N. R.R. Co., 118 F.R.D. 29, 33 (S.D.N.Y. 1987) ("Should defendants be permanently enjoined from prematurely releasing the ... lien ... that lien would cease to confer any 'hold-up' value on the bonds."). 
performing an injunction. The plaintiff's injunctive right would be freely alienable to anyone except the defendant. Plaintiffs worried that legal remedies would be inadequate would still be free to seek injunctions, but the inalienability of the injunction would tend to assure that it was sought for the performance itself and not for the extra bargaining power conferred by the threat of performance.

We then show that allowing the threatened party to adjust prospective damages seemingly against its own interest, what we call private additur and remittitur, can further undermine the credibility of the other side's threats. For example, if a defendant says that A dollars should be added onto any court-determined damage award (D), then a plaintiff must choose between the benefits of a possibly inalienable injunction and inflated expected damages $(D+A)$. Perversely, because of the possibility of inefficient threats, defendants can actually make themselves better off by petitioning the court to award larger damages and plaintiffs can make themselves better off by petitioning the coirt to award smaller damage.

\section{A. The Inalienable Injunction Option}

Figure 3 illustrates the potential of an inalienability option to deter threats of inefficient injunctive performance. For concreteness, assume an encroachment dispute in which the defendant's cost of removing the encroachment is 30 , the plaintiff's benefit of unencroached land is de minimis $(=0)$, expected damages are 1 , and the expected negotiated payment, if an alienable injunction issues, is $15 .^{58}$ These were the same numbers used above in Figure 1, where we saw that the plaintiff, under existing law, has an incentive to threaten inefficient injunctive performance-even though damages are expected to be supercompensatory.

${ }^{58}$ Although we have chosen an encroachment setting, the simple economic structure might also capture many contractual disputes where the defendant's cost of performance ends up being far greater than the plaintiff's benefit from performance. 


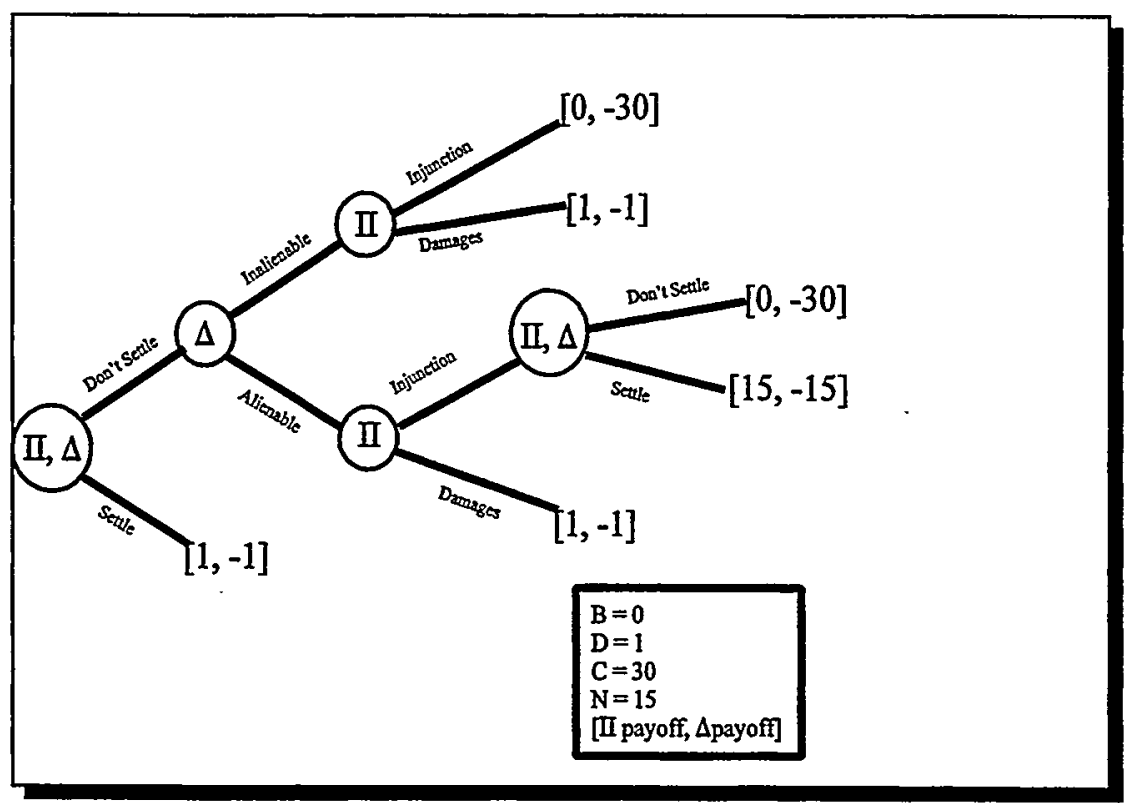

Figure 3: Inalienability Option Undermines Credibility of Plaintiff Injunction Threat

The game tree in Figure 3 is modified, however, to give the defendant an option to make any injunction awarded inalienable..$^{59}$ If the underlying values $\left(\mathrm{B}, \mathrm{D}, \mathrm{C}\right.$, and $\mathrm{N}$ ) are common knowledge, ${ }^{60}$ the defendant foresees that if she chooses inalienability, the plaintiff will have an incentive to opt for monetary damages. The plaintiff prefers the damages option since actual performance of an inalienable injunction gives the plaintiff no benefit $(B=0)$, while damages are expected to be 1 . For this reason, if the defendant elects "inalienabil-

${ }^{59}$ The order of play in the game is as follows: in the first stage, the parties negotiate; in the second stage, the defendant chooses whether an injunction would be inalienable or not; in the third stage, the plaintiff elects injunctive or damage relief; and finally, if the defendant has chosen alienability in the second stage and the plaintiff has chosen injunctive relief in the third stage, the parties then have an opportunity to bargain to discharge the injunction.

${ }^{60}$ See Ayres \& Nalebuff, supra note 1, at 1632 n.2 ("Something is common knowledge if it is known to each player, and, in addition, each player knows that the other player has this knowledge; knows that the other person knows the player knows it; and so forth." ) (quoting DOUGLAS G. BAIRD ET AI., GAME THEORY AND THE LAW 304 (1994)). 
ity," she will pay damages of only 1 . In contrast, choosing "alienable" would recreate the plaintiff's incentive to threaten inefficient performance and hence would lead to a much larger payment $(N=15)$. In equilibrium, the parties are likely to settle initially for 1 (since they know that this will be the outcome if they continue to progress through the stages of the game). ${ }^{61}$

In order for inalienable injunctions to deter inefficient injunctive threats effectively, it is important that: (1) the defendant be able to move first, i.e., be able to commit to inalienability before the plaintiff commits to injunctive relief; and (2) the parties not be allowed to "settle" a case for money once the defendant commits to inalienable injunctive relief. If the court first asks the plaintiff whether he wants injunctive relief and only then asks the defendant whether the

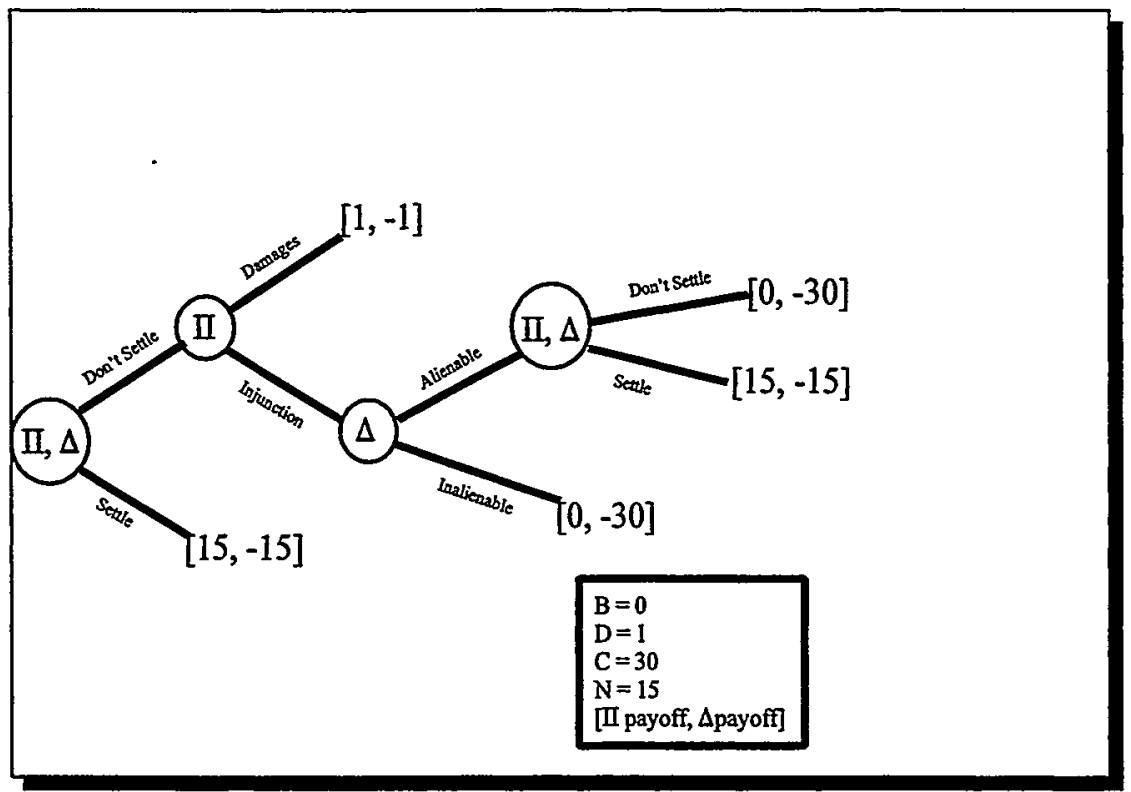

Figure 4: Inalienability Option Only Effective if Defendant Chooses First

${ }^{61}$ This simple game excludes negotiation and litigation costs. Adding these costs does not, however, qualitatively change the central result that giving defendants an inalienability option can deter plaintiff' incentives to seek inefficient injunctions. 
injunction should be inalienable, the plaintiff will still threaten an injunction. ${ }^{62}$ Under this scenario (as illustrated in Figure 4), once the plaintiff commits to an injunction, the defendant will choose to have the injunction be alienable so that she can avoid paying 30 . The inalienability option is only effective in deterring inefficient injunction threats if the defendant can commit to inalienability before the plaintiff commits to an injunction.

Moreover, inalienability options will only be effective if the court can enforce their inalienability, i.e., if they can prohibit monetary settlements of lawsuits after a plaintiff has opted for an inalienable injunction. In many litigation settings, one can imagine a delay of several weeks between the time that a plaintiff opts for injunctive relief and the time that the court actually issues the injunction. If plaintiffs know that they will have an opportunity to bargain to settle a lawsuit for monetary damages before an injunction is actually issued, then notwithstanding the defendant's choice of "inalienability," plaintiffs will seek an injunction in order to gain bargaining power to settle the case before the injunction actually issues. As shown in Figure 5 below, the ability to settle for money after the defendant and plaintiff opt for "inalienable" and "injunction" respectively fails to deter inefficient injunctive threats. The plaintiff forces a negotiation with the same expected payoff as we saw under the current injunctive scheme (in Figure 1) without an inalienability option for the defendant.

Indeed, even if the court prohibits monetary settlements (in the interim between the plaintiff's election of injunctive relief and the actual issuance of the injunction), the court also needs to worry that the parties will negotiate a monetary settlement after an injunction issues, notwithstanding the nominal inalienability of the court's order. After the fact, the parties will have a joint interest in negotiating away the inefficiency of the injunction and may be willing to collude to circumvent the inalienability restriction. To create the beneficial ex ante effects of the inalienability restriction, courts therefore will need to deter ex post settlements.

62 This analysis suggests that by adhering to the traditional election-of-remedies doctrine (which required plaintiffs to initially choose, and thereby be wedded to, a prayer for either monetary or injunctive relief), courts may unwittingly facilitate plaintiffs in threatening inefficient injunctive performance. SeeYORIO, supra note 16, at 213 ("IIn] the traditional election-of-remedies doctrine ... the plaintiff was required to choose-and be wedded to-a single remedial theory."). 


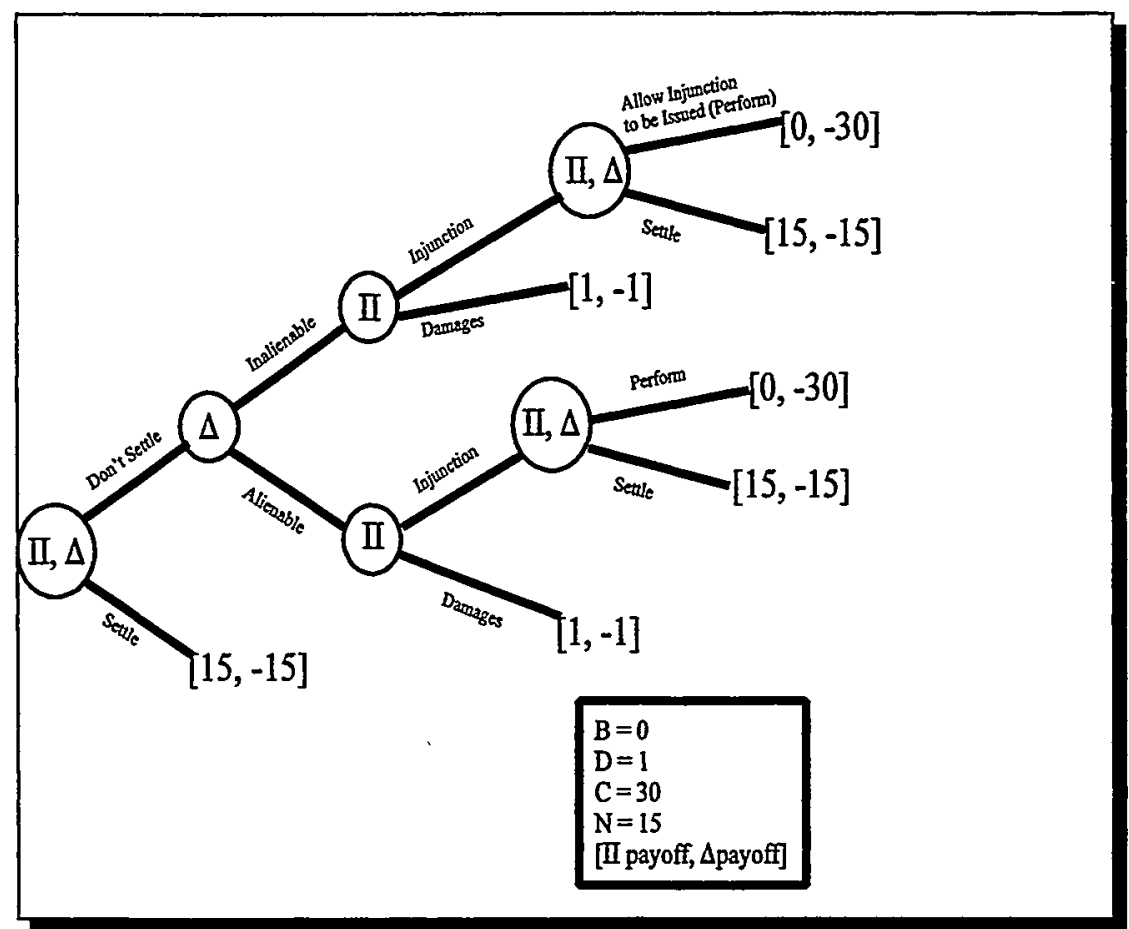

Figure 5: Inalienability Option Ineffective If Parties Can Settle Before Injunction Issued

Courts could accomplish this in many settings by placing judicial liens on defendants' property that would only be lifted on proof to the court that the defendant had actually performed the injunction. Courts would find verifying actual performance easiest in contexts involving positive, durable injunctions-that is, orders that defendants do a particular act one time. For example, in Pile the court could have refused to lift a judicial lien until it was shown photographic proof that the fence was removed. In contrast, it would be much harder for courts to deter ex post settlements concerning negative, non-durable 
precautions-that is, orders that defendants should not do a particular act over time. For example, if a court ordered a defendant not to trespass on the plaintiff's adjoining driveway, the court would have trouble verifying whether the parties covertly cut a deal to settle (i.e., nullify) an inalienable order. Even here the court might offer bounties to third parties who provide evidence of such a settlement. The court could threaten contempt sanctions, including jail for defendants who fail to perform inalienable injunctions and for plaintiffs who accept ex post payments. ${ }^{63}$

The take home lesson of this section is that a properly implemented inalienable injunction may, in at least some contexts, deter plaintiffs from threatening inefficient injunctions. ${ }^{64}$ It is important to emphasize, however, that the examples thus far have concerned only supercompensatory damages $(\mathrm{D}=1>\mathrm{B}=0)$, what we earlier called Range $2{ }^{65}$ Inalienable injunctions deter plaintiffs from making inefficient performance threats when damages are supercompensatory (Range 2), but inalienable injunctions might actually induce inefficient performance when damages are subcompensatory (Range 1). When damages fail to make the plaintiff whole, the plaintiff will continue to prefer injunctive relief-even if the injunction is inalienable. For example, if we change the foregoing example by raising $B$ from 0

${ }^{63}$ For the inalienability commitment to be effective, the court must not only have knowledge of whether the injunction is actually performed, but must also have the political will to follow through and require inefficient performance over the ex post protests of both the plaintiff and defendant. In certain contexts, the judicial lien may be sufficient to apprise the court of performance, but the difficulty of assuring the court's political will may be another reason to favor the judicial remittitur alternative discussed below in the text accompanying notes 119-20. The civil contempt power is discussed extensively in Bagwell v. International Union, 423 S.E.2d 349, 356 (Va. 1992), rev'd, 512 U.S. 821 (1994).

${ }^{64}$ Defendants may, as a theoretical matter, already be able to privately opt for inalienability-by entering into a Schelling-like commitment contract with a third party. See generally Thomas C. ScheldING, THE STRATEGY OF CONFLICT 22-28 (1960) (describing the benefits of introducing a third party into two-party negotiations). Under such a contract, the defendant would promise to pay a third party some outrageously large sum if the defendant were ever found to have negotiated her way out of a duty to perform. Such contracts would not completely destroy the incentive to negotiate one's way out of performance, rather the incentive would now exist for the defendant to pay off the third party as well as the plaintiff to avoid performance. If effective third-party commitment contracts are feasible, one might expect a commitment race whereby plaintiffs sought to commit to seeking an injunction before the defendant committed to inalienability.

${ }^{65}$ See supra discussion accompanying Table 1 (introducing the concept of ranges of super- and subcompensatory damages). Ranges 3 and 4 also concern supercompensatory damages, but as discussed above, since $\mathrm{D}>\mathrm{N}$ in these ranges, the plaintiff would not desire to replace court-ordered damages with injunctive relief. 
to 2 (holding $\mathrm{D}=1, \mathrm{C}=30$, and $\mathrm{N}=15$ constant), ${ }^{66}$ then the plaintiff would opt for an injunction over damages, even if the defendant had previously declared that any injunction would be inalienable. The plaintiff prefers an inalienable injunction under this fact pattern because it produces a payoff of 2 while court-ordered damages produce a payoff of only 1 . Even though performance of the injunction is massively inefficient $(C=30>B=2)$, the plaintiff still prefers actual performance to damages. When damages are subcompensatory, both parties may be worse off with an inalienable injunction than with an alienable injunction. ${ }^{67}$

The possibility of subcompensatory damages thus provides a strong reason for not asking courts to routinely make injunctions inalienable. Inalienablility is an effective deterrent in Range 2, but courts will often have difficulty determining whether damages are sub- or supercompensatory, i.e., whether the parties are interacting in a Range 1 or a Range 2 context. The magnitude and direction of D's deviation from $B$ may depend on the plaintiff's subjective valuation of $B, a$ valuation that may be difficult to verify. Instead of asking courts to impose inalienability only when the court is confident that damages are not subcompensatory, we prefer giving defendants the inalienability choice. This preference is motivated by our belief that the defendants are likely to be better informed about the underlying relationships among the values of $B, C, N$, and $D$. We cannot see why a court should impose an inalienability restriction when the defendant objects. If the defendant thinks that inalienability would fail to deter a plaintiff from seeking an injunction, we think courts should generally defer to the defendant's judgement.

The inalienability restriction is a natural outgrowth of courts' concern about issuing injunctions that impose undue burdens. We envision that courts at times should continue to deny injunctions when they are confident that a plaintiff is seeking the injunction as a bargaining chip to supplement otherwise adequate damages. In other settings, when the court is suspicious that the plaintiff is merely trying to threaten inefficient injunctive performance, the court might propose inalienability and ask if the defendant objects or give the defendant the option of making any injunction inalienable.

66 Assuming that $N$ is unchanged (when $B$ increases) effectively increases the defendant's bargaining power. Alternatively, we could assume that bargaining power $(\alpha)$ is unchanged and increase $\mathrm{N}$ to 16 .

${ }^{67}$ Anticipating the possibility of inefficient performance, parties in a "Range 1" situation are likely to settle for $\mathrm{N}$ before the defendant chooses "inalienability." 


\section{B. The Defendant's Damage Adjustment Option-Private Additur}

Granting defendants an inalienability option is effective in deterring performance threats where the court is likely to award supercompensatory damages in Range 2, but making the injunction inalienable will not deter plaintiffs from seeking injunctions where the court is likely to award subcompensatory damages (Range 1). Indeed, even if the court is expected to issue precise make-whole damages (D $=\mathrm{B}$ ), the plaintiff will have a credible threat to seek an inefficient injunction-because an inalienable injunction will make the plaintiff just as well off as monetary damages. To deter plaintiffs from seeking inefficient injunctions when damages are subcompensatory or exactly compensatory $(D<B)$, something more than inalienability is needed.

To solve this Range 1 problem, we recommend giving defendants a "private additur" option in addition to the "inalienability" option described above. Before a plaintiff is allowed to commit to injunctive relief, the defendant would be able to commit to paying an "additur" amount (A) in addition to any damages awarded by a jury. If the plaintiff chooses monetary instead of injunctive relief, the defendant would be required to pay $A$ in addition to any amount awarded at trial. The ultimate trier of fact would remain uninformed about the additur arrangement so that $D$ would be unaffected. ${ }^{69}$ This private additur option would accordingly have the effect of raising the plaintiff's expected payoff of monetary damages from $D$ to $D+A^{69}$

If we analyze a Range 1 example, we can see that the additur option in combination with the inalienability option can deter a larger range of inefficient performance threats than the inalienability option alone. If $\mathrm{D}=1, \mathrm{~B}=2, \mathrm{~N}=15$, and $\mathrm{C}=30$, a defendant would have an incentive to choose inalienability and to choose $A=1+\varepsilon$. The plaintiff would now face the choice of receiving the benefits of an inalienable injunction $(B=2)$ or the benefits of monetary relief $(D+A=2+$ $\varepsilon)$. The plaintiff in pretrial negotiations could threaten to seek an injunction unless the defendant pays 15 , but this threat would no longer be credible. In the absence of agreement, the plaintiff would seek monetary relief instead of an inefficient injunction.

${ }^{69}$ The court would need to require a litigation bond or establish a damage escrow to ensure that the defendant would be ablè to pay $D+A$.

69 The additur regime might instead be structured to allow the additur amount to be a function of the damages amount-so that the defendant could guarantee the plaintiff a minimum level of damages. 
Perversely, the defendant is made better off by asking the court to increase the potential damages it must pay. While this result seems nonintuitive, Eric Rasmusen has noted: "One of game theory's most profound lessons ... is that a player can benefit from new rules which reduce his payoffs on out-of-equilibrium paths." ${ }^{\text {70 }}$ By invoking the private additur option, the defendant lowers her expected payment from 15 to $2+\varepsilon$; without a damage increase, the defendant would expect the plaintiff to seek an injunction, and therefore would be willing to pay 15 to avoid incurring the cost of performance of 30 . Private additur changes the plaintiff's threat point in any pretrial negotiation. Without private additur, the plaintiff in the absence of agreement faces a choice between monetary and injunctive relief. Since by assumption in Range 1 monetary relief is inferior to the benefits of actual performance, the plaintiff can credibly threaten to seek an injunction. But private additur changes the plaintiff's best alternative. With private additur, monetary relief (yielding $2+\varepsilon$ ) now dominates the benefit of seeking actual performance (2).

In simple models, the defendant would need to make the net monetary damages only infinitesimally larger than $\mathrm{B}$ in order to deter the plaintiff from seeking an injunction. In more complicated models (for example where the defendant is uncertain about the size of B) and in the real world, however, we believe that defendants would set additur amounts to make net damages substantially exceed their estimates of B. In the foregoing example, a defendant might set net damages at 8 or 10 , as well as opt for inalienability, to increase the chance that the plaintiff would be sacrificing not a trivial amount to follow through on her threat, but a more substantial shortfall ( 8 or 10 as opposed to 2).

It will strike many readers that defendants already have an option of private additur because a defendant in pretrial negotiations can directly offer to settle the case for $\mathrm{D}+\mathrm{A}$. There is a crucial contractual distinction, however, between settlement offers and private additur offers. A defendant's settlement offer is not "firm" and hence its effectiveness can be destroyed merely by a plaintiff's rejection. The traditional common law rule is that an offeree's rejection or counteroffer destroys an initial offer. ${ }^{71}$ Accordingly, a defendant's settlement offer

${ }^{70}$ Eric Rasmusen, Book Review, 33 J. ECON. LITERATURE 1979, 1980 (1995) (reviewing KEN BINMORE, 1 GAME THEORY AND THE SOCIAL CONTRACT: PLAYING FAIR (1994)). Here a player benefits from reducing her payoff on what was an out-ofequilibrium path-in order to make it (monetary relief) an equilibrium path.

${ }^{71}$ See, e.g., Beverly Way Assocs. v. Barham, 276 Cal. Rptr. 240, 244 (Ct. App. 1990) 
is not effective in changing the plaintiff's BATNA. In Range 1, if the defendant offers to pay the plaintiff 3 to settle the suit, the plaintiff by merely responding "no" destroys the defendant's offer and again makes credible the threat of seeking an injunction. Since the private additur amount is an irrevocable offer to settle, the plaintiff's resistance cannot change the fact that the plaintiff, in electing remedies, must choose between an inalienable injunction yielding $B$ and money damages of $\mathrm{D}+\mathrm{A}^{72}$

By making a firm commitment to pay higher monetary damages (and by opting for inalienability of any injunction), defendants can deter plaintiffs' inefficient performance threats and thereby decrease their ultimate expected payment. Defendants will only exercise their private additur option when they believe court-awarded damages will be undercompensatory, in order to discourage plaintiffs from seeking inefficient injunctions. The additur option harnesses defendants' private information in an attempt to transform subcompensatory awards into awards that better approximate make-whole compensation. The additur option allows a defendant to convert a Range 1 undercompensatory threat into a Range 2 supercompensatory threat, which then can be deterred by making the injunction inalienable. If defendants find it in their self-interest to commit to paying higher damages (in order to deter plaintiffs from seeking inefficient injunctions), courts should acquiesce in their requests. ${ }^{73}$

("It is hornbook that an unequivocal rejection by an offeree, communicated to the offeror, terminates the offer ...."); RESTATEMENI (SECOND) OF CONTRACTS § 36 (1979) (stating that a rejection or counter-offer terminates the offeree's power of acceptance). The U.C.C. already allows merchants to make limited firm offers regarding the sale of goods. See U.C.C. $\S 2-205$ (1962) ("An offer by a merchant to buy or sell goods in a signed writing which by its terms gives assurance that it will be held open is not revokable...."). The U.C.C. provisions, however, would not apply to most settlement negotiations and the firmness created by the U.C.C. does not nearly match the firmness the court could demand with performance bonds and escrows and even the possibility of contempt proceedings if the defendant failed to live up to her additur offer.

${ }_{72}$ The private additur offer is not structurally the same as a take-it-or-leave-it offer because we would allow either the plaintiff or the defendant to make additional nonfirm offers. Still, the irrevocability of the private additur offer in this model has the same effect as giving the defendant the right to make a take-it-or-leave-it offer. The defendant would never have an incentive to make other offers or to accept other offers from the plaintiff. The private additur offer effectively limits the plaintiff to one of two choices: accepting or rejecting monetary damages.

${ }_{73}$ A caveat to this proposal and others in this paper is that in the contractual setting we would propose that inalienability and damages adjustment options be just default rules. See infra Part IV.A. 


\section{The Plaintiff's Damage Adjustment Option-Private Remittitur}

An analogue to private additur can similarly be used to deter potential defendants from threatening inefficient performance when damages are in Range 4. As discussed earlier, if potential damages equal or exceed the defendant's cost of performance, the defendant will credibly threaten to perform unless the plaintiff accepts a payment substantially less than damages. Thus, if $B=0, N=15, C=30$, and $\mathrm{D}=32$, before breaching the defendant will threaten to perform if the plaintiff does not accept 15 in lieu of performance. The defendant's threat is credible because in the absence of agreement, the defendant would rather perform her duty at a cost of 30 than pay 32 in damages.

It is again possible to give the threatened party options to undermine the credibility of the other side's threats. Just as we gave defendants additur options to counter the possibility of plaintiff performance threats, it is possible to give plaintiffs a "remittitur option" to counter the possibility of defendant performance threats. A remittitur option would allow the plaintiff to announce a remittitur amount (R) by which any court award would be reduced. For example, if the jurisdiction is likely to impose cost of performance damages (D), the plaintiff could announce that the defendant would only have to pay $D$ - $R$. In the foregoing Range 4 example $(B=0, N=15, C=30$, and $D=$ 32 ), the plaintiff would have an incentive to set $R$ equal to $2+\varepsilon$. Doing so would reduce the defendant's net expected damages to $30-\varepsilon$ and thereby undermine a threat to perform (at cost 30 ) if negotiations failed. ${ }^{74}$

Giving plaintiffs an option to reduce the amount they would receive in damages increases their expected payment. In the foregoing example, if the plaintiff fails to reduce expected damages (setting $R=$ 0 ), the defendant will be able to credibly threaten performance and thereby negotiate a payment of only 15; but if the plaintiff reduces his expected monetary damages by a little more than 2 , the defendant will

${ }^{74}$ Our discussion of Bebchuk suggests that when performance costs are incurred over time, a defendant may under some circumstances credibly be able to threaten performance even when the total costs of performance are greater than the expected damages the defendant would have to pay for breaching. See supra notes 37-39 and accompanying text. Even when the Bebchuk result holds, however, this simply means that there will be some critical level $\mathrm{C}^{*}<\mathrm{C}$ that will determine when a defendant threat will be credible. Under the Bebchuk variation, the defendant would set the remittitur amount so that $\mathrm{D}-\mathrm{R}<\mathrm{C}^{*}$ to render the defendant's performance threat noncredible. 
simply breach the contract and pay the plaintiff an amount much closer to 30 .

Just as defendant additur could change the plaintiffs BATNA when the plaintiff was threatening an inefficient injunction, plaintiff remittitur can change the defendant's threat point. In Range 4, the defendant's best alternative to a negotiated agreement is to perform her duty, but the remittitur makes the defendant's best alternative failing to perform her duty (and paying damages) if the parties cannot agree to an alternative arrangement. ${ }^{75}$ Plaintiffs will only take the extreme step of committing to lower damages if they believe doing so will counteract the defendant's threat to behave inefficiently. As with defendant additur, the option is self-regulating. Plaintiffs will have no incentive to set the remittitur amount too high.

An important problem with implementation, however, concerns the procedural setting of defendant threats. Since potential defendants use the threat of performance before performance is due, potential plaintiffs under current law would not have standing to bring suit, much less announce a remittitur amount. For example, in the contractual setting, a promisor who uses a performance threat to negotiate a settlement price that is less than the expected damages would not give the promisee a basis for filing a lawsuit. The threat not only occurs before performance is due, but the threat to perform is the antithesis of anticipatory repudiation. Perversely, a promisor's threat is more akin to what the U.C.C. calls giving adequate assurance that, notwithstanding higher costs, the promisor still intends to perform when performance comes due. ${ }^{76}$ Yet while it is necessary for a promisee to be able to commit before a breach to seek $\mathrm{R}$ less than a jury would normally award, it is not necessary that the commitment be filed with a court. It is only necessary that the law allow potential plaintiffs to make irrevocable offers to reduce potential damages at the time the potential defendant threatens breach. In the end, these problems of implementing plaintiff remittitur are not of great concern-because the next section finds that even a perfectly implemented regime often does not further net equity and efficiency. Thus, while we favor defendant inalienability and additur options, we disfavor the use of plaintiff remittitur to deter defendant performance

${ }^{75}$ As emphasized above, a remittitur offer, unlike a mere settlement offer, cannot be destroyed by the other side's rejection of the offer.

${ }^{76}$ See U.C.C. \$ 2-609(1) (1989) ("When reasonable grounds for insecurity arise with respect to the performance of either party the other may... demand adequate assurance of due performance...."). 
threats.

Table 1 identified credible performance threats supported by three different damage ranges. In this section we have shown three ways to modify current remedial doctrines to discourage such threats. Giving defendants an inalienability option was sufficient to deter Range 2 plaintiff threats; this inalienability option and defendant additur together were sufficient to deter Range 1 plaintiff threats; and finally, plaintiff remittitur was sufficient to deter Range 4 defendant threats. In each of these settings, by giving the threatened party countervailing options, courts can harness private information to deter threats of inefficient performance. Rendering such threats noncredible is likely to reduce the costs of negotiation because the parties have little, if anything, about which to negotiate. Such efficiency effects are properly the topic of the next section.

\section{SHOULD THREATS OF INEFFICIENT PERFORMANCE BE DETERRED?}

Just because the law can be structured to deter threats of inefficient performance does not mean that the law should be so structured. Indeed, this section argues on the basis of equity and efficiency that the law should presumptively use injunctive inalienability and defendant additur to deter plaintiff performance threats, but should not try to deter defendant performance threats.

\section{A. Equity}

The strongest rationale for deterring plaintiff performance threats is the equitable impulse to deter plaintiff overcompensation. Plaintiff threats increase the risk of plaintiff overcompensation, while defendant threats reduce the risk of plaintiff overcompensation. As shown above in Table 1, plaintiffs will at times seek injunctions instead of supercompensatory damages because they expect to extract an even larger amount from defendants if injunctive performance is threatened. $^{77}$

By contrast, defendant threats reduce the risk that defendants will

${ }^{77}$ Table 1 also showed, however, that plaintiffs may also threaten injunctions when damages are subcompensatory (Range 1 ). In such circumstances, the plaintiff's threat substitutes an inequitable supercompensatory payoff for an inequitable subcompensatory payoff. However, as performance becomes increasingly inefficient $(C>B)$, it becomes increasingly likely that plaintiff performance threats will cause a larger absolute deviation from make-whole damages $(B)$-that is, $(B-D)<(N-B)$. 
have to overcompensate plaintiffs. Credible defendant threats of inefficient performance occur when expected damages are supercompensatory $(D>C>B$ ) and have the effect of reducing the plaintiff's payoff toward make-whole damages. Moreover, defendant threats reduce the risk of plaintiff overcompensation without increasing the risk of plaintiff undercompensation. Defendant threats are useful only in inducing plaintiffs to accept some amount between a minimum defined by the plaintiff's benefit from performance and a maximum defined by the defendant's cost of performance. There are no conditions under which a plaintiff can be induced to accept a settlement amount less than its valuation of performance, for the simple reason that a plaintiff faced with such an offer would tell the defendant to go ahead and perform.

Inalienable injunctions combined with defendant additur share the equitable traits of defendant threats: they reduce the risk that defendants will be forced to overcompensate plaintiffs without increasing the risk that plaintiffs will be undercompensated. Courts at times issue what they have every reason to believe are inefficient injunctions $(B<C)$ because they have a strong aversion to the possibility that a comparatively innocent plaintiff will be undercompensated. Giving plaintiffs the remedial choice of injunctive or monetary relief helps assure that plaintiffs will not be undercompensated, because plaintiffs can always choose the performance that is due them. The current practice of giving plaintiffs the choice of alienable injunctions, however, leads to the obverse risk-that plaintiffs may be massively overcompensated by using injunctions to bargain for settlement amounts that may be as much a function of the defendant's cost of performance as they are the plaintiff's valuation of performance. Instead of giving plaintiffs the weapon of alienability, we prefer a regime that preserves plaintiffs' unfettered rights to actual performance of the duty they are owed but which undermines their ability to bargain for a payoff in excess of the amount by which they value performance. Making injunctions inalienable does just this. Inalienability does not increase the risk that plaintiffs will be undercompensated, because they can still opt for specific performance, but it does reduce the risk that defendants will be forced to overcompensate plaintiffs by limiting plaintiffs' opportunities to use injunctive remedies merely as a strategic tool for extracting high settlements.

The foregoing discussion of over- and undercompensation implicitly assumes, however, that a plaintiff is only entitled to the "use value" of performance-that is, the benefits that flow to the plaintiff from 
the defendant actually performing (or the monetary equivalent of this value). In some settings, however, it is possible to think that a plaintiff should have a right to either use or sell a particular right at stakeand that by granting an alienable injunction a court merely maintains the plaintiff's "exchange value" of the right in question. For example, if a landowner (Pedrick), after initially attempting to buy a small strip of land from his next door neighbor (Pile) then "willfully" encroaches, a court in equity may want to issue an alienable injunction to recreate the bargaining setting that the defendant wrongfully avoided. In such settings, a payment negotiated in the shadow of an alienable injunction $(N)$ may be more equitable than a payment which more closely approximates the plaintiff's use value (B). ${ }^{78}$ Accordingly, courts might usefully distinguish between mistaken and willful encroachment-granting inalienable injunctions only for the former. More generally, "exchange value" injunctions may be appropriate whenever a plaintiff has wrongfully converted a defendant's exchange right.

Courts should consider whether in issuing an injunction they seek to protect merely the plaintiff's "use value" or the plaintiff's "exchange value." Even though property rights are said to traditionally include the right to exclude, ${ }^{79}$ and hence the right of a property owner to resist selling to enhance her exchange value, most contracts intend to give the promisee only the use value of consideration and not the right to hold up the promisor for sums disconnected from the promisee's "expectation." In the end, distinguishing between "use value" and "exchange value" entitlements restricts the application of our analysis but still leaves a vibrant class of cases in which defendant inalienability and additur could further equity.

Finally, there is also an equitable sense in which inalienable injunctions help deter fraud on the issuing courts. Plaintiffs seeking injunctions may represent that monetary relief could not make them whole and then figuratively turn around before the ink is dry on the injunction and start bargaining for monetary relief. The attempt to sell injunctive rights is not necessarily fraudulent; a finding of fraud would turn on the often implicit representations made during litiga-

${ }^{78}$ As discussed infra at note 114 , however, an injunction does not necessarily recreate the bargaining setting the parties initially faced. After the wall is built, the bargaining situation has fundamentally changed, and the resulting bargain (which now depends on the cost of wall removal) may be drastically different than it would have been earlier.

${ }^{79}$ See Robert C. Ellickson, Property in Land, 102 YALE L.J. 1315, 1363 (1993) (discussing idealized Blackstonian bundle of property rights). 
tion. Still, one can easily imagine that many courts fail to consider that injunctions they grant may be bargained away. ${ }^{80}$ At a minimum, it might be useful for courts in deciding whether monetary damages are inadequate to have an explicit dialogue with plaintiffs about whether they intend to sell their injunctive right and if so, for how much.

\section{B. Efficiency}

The efficiency effects of moving to a system of inalienable injunctions and defendant additur are more muddled. While our proposed reform has the salutary effect of moving the plaintiff's expected payoff toward expectation damages, law and economics scholars in the last decade have found it increasingly difficult to conjure a single damage measure that induces both sides to behave efficiently on a variety of dimensions both before (ex ante) and after (ex post) a potential breach. $^{81}$ This section shows that our reform proposal-giving defendants the choice of inalienability and additur-is likely to induce more efficient defendant precaution and risk allocation. We also show limited conditions under which our proposal could enhance the efficiency of plaintiff reliance and ex post bargaining.

While much of our analysis derives from the literature on efficient contract damages, the analysis can be extended to noncontractual settings as well. For example, in our earlier encroachment example, defendant precautions (in reducing $\mathrm{C}$ ) could alternatively be modeled as precautions to avoid negligent encroachment and plaintiff reliance (in increasing B) could be modeled as actions that either mitigate or fail to mitigate the plaintiff's damages from such encroachment. In some non-contractual contexts, however, the ex ante effects of inalienability and additur are likely to be much more attenuated. In such settings, the utility of our reform proposal turns instead on equitable and ex post bargaining considerations. note 3

${ }^{80}$ Judge Richard Posner is a notable exception. See supra text accompanying

${ }^{81}$ Some scholars have shown, however, certain contexts in which parties can induce efficient investment by agreeing to alienable injunctions (ordering specific performance of the original contract if parties fail to renegotiate). See, e.g., Philippe Aghion et al., Renegotiation Design with Unverifiable Information, 62 ECONOMETRICA 257, 268 (1994) (arguing that when one party is given "the adequate choice of the default option," and the other is endowed with all the bargaining power, efficient investments can be achieved). 


\section{Ex Ante Effects on Defendant Precaution, Plaintiff Reliance, and Risk}

Contract remedies can affect not only who will bear the risk of inefficient performance (the risk that $\mathrm{C}$ will end up being greater than B) but also the size of this risk by affecting plaintiffs' and defendants' incentives to make investments that change the expected benefits and costs of performance. Damages can affect the defendant's precautionary investment in reducing $\mathrm{C}$ and the plaintiff's reliance investment in increasing $\mathrm{B}^{82}$ This section analyzes the effect of giving defendants inalienability and additur options on the ex ante efficiency of defendant precaution, plaintiff reliance, and the parties' risk allocation.

The willingness of defendants to invest in reducing $\mathrm{C}$ and the willingness of plaintiffs to invest in increasing $B$ will turn, in part, on their expectations about how their respective investments will affect the size of the payment that the defendant will make to the plaintiff if performance does not occur. If the expected payment is tied exclusively to the plaintiff's benefit and is therefore disconnected from the defendant's cost, then the defendant will have an incentive to invest efficiently in precaution, and the plaintiff will have an incentive to invest excessively (from an efficiency standpoint) in reliance. This is a slight generalization of the standard result that expectation damages lead defendant/promisors to make efficient investments to protect against unexpected increases in the cost of performance. ${ }^{83}$ The defendant/promisor acts efficiently because, otherwise, she will have to pay the plaintiff/promisee for the benefits the latter has forgone because of the breach. Expectation damages thus measure the real social cost of failure to perform. Tying the level of damages to the plaintiff's benefit makes the defendant a residual claimant with regard to her

${ }^{82}$ Recent work has also analyzed the effect of expected damages on "cooperative" investments-i.e., the possibility that plaintiffs could invest to reduce $C$ or that defendants could invest to increase B. See Yeon-Koo Che \& Tai-Yeong Chung, Contract Damages and Cooperative Investments, 30 RAND J. ECON. 84, 85 (1999) (defining a hypothetical "cooperative" investment by the seller as one that "increases the buyer's benefit (stochastically) without lowering the seller's cost of performance").

${ }^{83}$ See Shavell, supra note 26 , at 487 ("[U]nder the expectation measure, our results indicate that to the extent that each party ... believes he himself will default, he will engage appropriately in reliance ...."); see also Robert Cooter \& Melvin Aron Eisenberg, Damages for Breach of Contract, 73 CAL. L. REV. 1432, 1464 (1985) ("Expectation damages ... therefore cause the promisor to internalize the cost of his failure to take adequate precaution... and create incentives for efficient precaution against breach."). 
decision of how much to invest in reductions in C. As a residual claimant, the defendant bears the full costs and receives the full benefits of her decisions, so (to the extent she maximizes profits) she will make the socially optimal decision.

In contrast, a plaintiff anticipating expectation damages may not make the socially optimal decision. Tying the level of damages to the plaintiff's benefit externalizes the effects of the plaintiff's investment decisions. Under such a regime, in deciding whether to invest in increasing $B$, the plaintiff does not take into account the possibility that an increase in costs may cause performance to become inefficient. The plaintiff will receive $B$ in kind or in money regardless of whether the defendant performs-so the plaintiff has an incentive to rely excessively. ${ }^{84}$

A converse story holds for damages that are tied exclusively to the defendant's cost and are therefore disconnected from the plaintiff's benefit. If we put aside for a moment the possibility of defendant performance threats, then setting damages equal to the defendant's cost of performance makes the plaintiff a residual claimant with regard to his investments in increasing $B$. The plaintiff's reliance therefore will be limited since, in the event of breach, he may find it in his best interest to take $\mathrm{C}$ in cash (rendering worthless any investments that were to have paid off in the event of performance). At the same time, setting damages at cost of performance means that the defendant will no longer take into account $\mathrm{B}$ in determining precaution, only $\mathrm{C}$ itself. As a result, such a regime will cause the plaintiff to invest efficiently in reliance but will cause the defendant to invest excessively in precaution. In a world without defendant performance threats, defendants realize that they will be liable for paying the cost of performance (in kind or its monetary equivalent) whether or not performance turns out to be efficient, and thus they invest too highly in precautionary measures designed to limit their ultimate cost of performance.

The important lessons here are that (1) as the size of the expected defendant payment becomes less connected to the realized cost of performance, the defendant's incentives to invest in reducing $\mathrm{C}$ will become more efficient; and (2) as the size of the expected defendant

${ }^{84}$ A plaintiff excessively relies when the plaintiff makes an investment a profitmaximizing actor would not make if it had to absorb its own costs in the event of nonperformance. See Shavell, supra note 26, at 487 ("[T]o the extent that each party believes he will be the victim of a breach, he will engage in excessive reliance ...."); see also Cooter \& Eisenberg, supra note 83, at 1465-68 (discussing a party's "surplusenhancing reliance"). 
payment becomes less connected to the realized plaintiff benefit from performance, the plaintiff's incentives to invest in increasing $B$ will become more efficient. ${ }^{85}$ We were careful in the previous sentence to use the term "expected defendant payment" instead of "expected damages," because initial investments should turn not on nominal damages that the court might award, but, rather, on the actual payments that the parties expect in the shadow of potentially credible threats of inefficient performance. Thus, in a jurisdiction that awards cost of performance damages, the plaintiff and the defendant should expect a payment of $\mathrm{N}$ (to be negotiated when performance becomes inefficient) instead of a payment of $\mathrm{C}$.

Understanding how the ex ante investments of the plaintiff and the defendant will be tied to their expectations about the sensitivity of ultimate defendant payments to realized levels of the costs and benefits of performance allows us to assess the efficiency of deterring plaintiff and defendant threats. Table 2 shows, for the four damage ranges initially discussed in connection with Table $1,{ }^{86}$ how our proposals to deter performance threats would affect the expected defendant payment in the event that performance were to become inefficient. The table also summarizes the effects on different dimensions of ex ante efficiency. Pluses indicate that the proposed legal regime in question produces superior precaution, reliance, or risk allocation relative to the conventional regime. Minuses indicate that the alternative legal regime's expected outcomes are worse than those of the conventional regime.

${ }^{85}$ It is possible to have damages that are disconnected from marginal changes in both the defendant's cost and the plaintiff's benefit. Indeed, Cooter and Eisenberg have shown that a number of common law rules-for example, denying damages for excessive reliance-as well as liquidated damage clauses may have the effect of inducing efficient ex ante investment behavior of both plaintiffs and defendants. See Cooter \& Eisenberg, supra note 83, at 1467 (noting that, under existing law, "the expectation and reliance measures undoubtedly contemplate that only reasonable reliance will be compensated").

${ }^{86}$ See supra table in text accompanying note 50 (summarizing the effects of inefficienct threats in four defined damage ranges). 
Table 2: Efficiency Effects of Deterring Performance Threats

\begin{tabular}{|c|c|c|c|c|}
\hline $\begin{array}{c}\text { Possible } \\
\text { Damage Ranges } \\
\text { When } \\
\text { Performance is } \\
\text { Inefficient }\end{array}$ & $\begin{array}{c}(1) \\
\mathrm{D}<\mathrm{B}<\mathrm{N}<\mathrm{C}\end{array}$ & $\begin{array}{c}(2) \\
\mathrm{B}<\mathrm{D}<\mathrm{N}<\mathrm{C}\end{array}$ & $\begin{array}{c}(3) \\
B<N<D<C\end{array}$ & $\begin{array}{c}(4) \\
B<N<C<D\end{array}$ \\
\hline $\begin{array}{l}\text { Whose Threats } \\
\text { Are Credible }\end{array}$ & \multicolumn{2}{|c|}{$\begin{array}{c}\text { Plaintiff Threats } \\
\text { (potentially deterred by } \\
\text { inalienability and additur) }\end{array}$} & No Threats & $\begin{array}{l}\text { Defendant } \\
\text { Threats } \\
\text { (potentially } \\
\text { deterred by } \\
\text { remittitur) }\end{array}$ \\
\hline $\begin{array}{c}\text { Ultimate } \\
\text { Damage } \\
\text { Payment Under } \\
\text { Usual Regime } \\
\end{array}$ & $\mathbf{N}$ & $\mathrm{N}$ & D & $\mathbf{N}$ \\
\hline $\begin{array}{c}\text { Damage } \\
\text { Payment Under } \\
\text { Alternative } \\
\text { Threat Deterring } \\
\text { Regime } \\
\end{array}$ & $B+\varepsilon$ & D & $\mathrm{D}$ & $C-\varepsilon$ \\
\hline $\begin{array}{l}\text { Defendant } \\
\text { Investment in } \\
\text { Precaution (to } \\
\text { reduce G) } \\
\end{array}$ & + & + & & - \\
\hline $\begin{array}{c}\text { Plaintiff } \\
\text { Investment in } \\
\text { Reliance (to } \\
\text { increase B) } \\
\end{array}$ & - & $+?$ & & + \\
\hline $\begin{array}{c}\text { Risk Allocation } \\
\text { (when at least } \\
\text { one party is risk } \\
\text { averse) } \\
\end{array}$ & + & + & & - \\
\hline $\begin{array}{c}\text { Ex Post } \\
\text { Bargaining } \\
\text { Efficiency } \\
\end{array}$ & $?$ & + & & $?$ \\
\hline
\end{tabular}


When damages are below the amount that might be negotiated in the shadow of a performance threat (Ranges 1 and 2), a plaintiff, given a traditional choice of remedies, will seek an alienable injunction to increase his expected payment to $\mathrm{N}$. If, however, defendants know $\mathrm{B}, \mathrm{C}$, and $\mathrm{D}$ and are given the inalienability and additur choice, then they will deter the injunction threats. In Range 1, where damages are subcompensatory, the defendant will opt for inalienability and will choose an additur amount that causes the defendant's expected payment to slightly exceed the plaintiff's benefit of performance $(B+\varepsilon)$. In Range 2 , where damages are supercompensatory, the defendant will choose inalienability which, in turn, will cause the plaintiff to opt for damages of $\mathrm{D}$.

Giving defendants the inalienability and additur options increases the efficiency of their ex ante investments in reducing $\mathrm{C}$ because defendants' expected payoffs are less correlated with the ultimate size of C. If injunctions are alienable, the defendant expects to pay $\mathrm{N}$, which is explicitly a function of $\mathrm{C}$; when the parties have equal bargaining power, the negotiated payment $N$ will equal $(B+C) / 2$. This means that the defendant's precautions reduce not only the expected cost of performance, but also the expected payment when performance does not occur. Alienable injunctions thus will lead to excessive defendant investment. Inalienability and additur regimes, in contrast, create expected payments that are unconnected to the ultimate size of the defendant's cost of performance. In Range 1, the expected payment is slightly above the plaintiff's benefit from performance, and in Range 2 , the supercompensatory damage amount is, by assumption, more of an estimate (albeit overly generous) of the plaintiff's benefit than of the defendant's cost. Defendants' investments lower their costs when performance occurs but not when performance does not occur, so defendants have better incentives to take the efficient level of precaution. $^{87}$

${ }^{87}$ Table 2 also shows why giving plaintiffs remittitur options can exacerbate defendants' incentives to invest excessively in reducing their costs of performance. When defendants can credibly threaten performance in Range 4, they expect to pay an amount $(\mathrm{N})$ that is only partially responsive to reductions in $\mathrm{C}$. If the Nash bargaining outcome applies, every dollar reduction in $\mathrm{C}$ will lead to a fifty cent reduction in $\mathrm{N}$. If plaintiff remittitur is allowed, however, the defendant will expect to pay just slightly less than her cost of performance $(C-\varepsilon)$; if the defendant reduces cost of performance (C) by one dollar, she simultaneously reduces her damage payment for failure to perform $(C-\varepsilon)$ by one dollar. Since investments in reductions in $C$ greatly reduce the amounts that the defendant will pay when performance does not occur, a plaintiff remittitur regime will exacerbate defendants' incentives to invest excessively in precaution. 
While giving defendants inalienability and additur options unambiguously increases the efficiency of defendants' ex ante investments (in reducing $C$ ), the effect of deterring performance threats on plaintiffs' ex ante investments (in increasing B) is much more ambiguous. When court-awarded damages are expected to be less than the plaintiff's $B$ (i.e., when damages are in Range 1), the inalienability and additur options undermine the plaintiff's incentives to invest efficiently by making ultimate damage payments more sensitive to $B$. In the shadow of traditional alienable injunction threats, plaintiffs expect that an investment intended to increase the value of $B$ will be only partially recovered if performance does not occur. Under the Nash bargaining outcome, for example, plaintiffs would expect every dollar increase in $\mathrm{B}$ to result in only a fifty cent increase in $\mathrm{N}$, the payoff if the defendant fails to perform. Under the deterrence regime, however, a defendant will have an ex post incentive to announce an additur amount that raises its expected payment slightly above the plaintiff's realized benefit of performance $(B+\varepsilon)$. Accordingly, when defendant additur is allowed, plaintiffs will expect that investing to increase $B$ by one dollar will increase their expected payoff by one dollar whether or not performance turns out to be efficient. For this reason, deterring plaintiff threats in Range 1 exacerbates the plaintiff's incentive to over-rely.

In Range 2, however, a threat deterrence strategy may induce more efficient plaintiff investments in increasing B. The crucial question is whether the supercompensatory damages (D) are more or less sensitive to changes in B than the amount expected to be negotiated in the shadow of a performance threat $(\mathrm{N})$. This will turn in part on the relative bargaining power of the parties, but it is also partially dependent on the methodology by which the court calculates damages. Damage calculations that are generous but relatively insensitive to marginal investments to increase $B$ will tend to channel performance threats into Range 2 and give the plaintiff as well as the defendant incentives to make more efficient ex ante investments. ${ }^{83}$ Cooter and Eisenberg have suggested that several common law principles may already be in place to reduce the sensitivity of damages to excessive reli-

${ }^{8 s}$ While we do not endorse giving plaintiffs remittitur options to deter defendant performance threats, our analysis suggests that the remittitur option will tend to increase the efficiency of the plaintiff's investments. The remittitur option makes the defendant's expected payments less sensitive to $B$ than bargaining in the shadow of a credible performance threat. (This can be seen in Table 2, as $(C-\varepsilon)$ is less sensitive to changes in B than N.) As a result, plaintiffs risk losing more of their investment in B if performance becomes inefficient, and they therefore have less incentive to over-rely. 
ance. $^{89}$

Table 2 also shows that deterring plaintiff performance threats can lead to a more efficient allocation of risk when at least one of the parties is risk averse and the inefficiency of performance is due to an unexpected increase in cost. $^{90}$ Mitch Polinsky has shown that breach remedies allocate among the contractual parties the risk stemming from changes in circumstances. ${ }^{91}$ For example, Polinsky has shown that when production costs fluctuate, the optimal damage payment in terms of risk allocation will be somewhere between the plaintiff's ex ante expected benefit from performance (B) and the defendant's ex ante expected cost of performance $\left(\mathrm{C}_{\mathrm{ex} \text { ante }}\right) .^{92}$ Setting damages equal to $B$ is one way that the plaintiff can avoid risk-because the plaintiff will receive a (monetary or in kind) benefit equaling $B$ whether or not performance occurs, leaving the defendant to bear all the risk. ${ }^{93}$ If the defendant is risk averse and the plaintiff risk neutral, however, then the plaintiff should bear all the risk. Reducing damages from $B$ to $\mathrm{C}_{\text {ex ante }}$ has the effect of shifting risk from the defendant to the plaintiff. If the ultimate performance cost equals $\mathrm{C}_{\mathrm{ex} \text { ante }}$, the (party who would otherwise be a) defendant will perform and get her initial expected profit; if the performance cost rises above $\mathrm{C}_{\mathrm{ex} \text { ante }}$, the defendant will breach the contract and pay damages of $\mathrm{C}_{\mathrm{ex} \text { ante }}$ once again getting her initial expected profit. If both the plaintiff and the defendant are risk averse, then the ideal damage level from a risk allocation perspective would be somewhere between $\mathrm{C}_{\text {ex ante }}$ and $\mathrm{B}^{94}$

Inefficient threats can produce damage payments outside of this range. A plaintiff who threatens inefficient performance, for example, will expect to receive a payment of $N$, which exceeds the optimal risk-allocation damage range ceiling of $\mathrm{B}$. Having this option to seek

${ }^{89}$ See Cooter \& Eisenberg, supra note 83, at 1467 (stating that the existing practice of limiting damage awards to reasonable reliance costs makes damages somewhat insensitive to actual reliance).

${ }^{90}$ A similar analysis applies if performance becomes inefficient due to an unexpected decrease in the benefit of performance.

${ }^{91}$ See A. Mitchell Polinsky, Risk Sharing Through Breach of Contract Remedies, $12 \mathrm{~J}$. LEGAL STUD. 427 (1983), for a discussion of optimal risk allocation under various circumstances, including different reasons for breach and different risk preferences among buyers and sellers.

${ }_{92}$ See id. at 442 (discussing optimal damage payments when production costs fluctuate).

${ }^{93}$ See id. at 443 (explaining that if the buyer is risk averse and the seller is risk neutral, the optimal damage payment equals the buyer's benefit).

${ }^{94}$ See id. at 442 (explaining that if both parties are risk averse, the optimal damage payment is between the seller's normal production cost and the buyer's benefit). 
high damages effectively forces the plaintiff to buy and forces the defendant to sell a lottery ticket. The plaintiff bears the risk of receiving, and the defendant bears the risk of paying, a supercompensatory amount in the event performance does not occur. Deterring plaintiff performance threats with inalienability and additur options reduces the lottery component of nonperformance by reducing damages from $\mathrm{N}$ down to $\mathrm{D}$ or $(\mathrm{B}+\varepsilon)$ and, thus, provides a more efficient risk allocation if at least one of the parties is risk averse.

\section{Ex Post Effects}

Threatening inefficient performance may occasion needless costs of bargaining and, if bargaining breaks down, result in inefficient performance. These ex post bargaining inefficiencies are largely a function of the parties' potentially imperfect information. While plaintiffs are likely to know the value of receiving defendants' performance (B) and defendants are likely to know the cost of performing $(C)$ as performance becomes due, the parties may not know each other's valuation. When plaintiffs are imperfectly informed about $\mathrm{C}$ and defendants are imperfectly informed about $\mathrm{B}$, ex post bargaining may be inefficient.

When damages fall in Range $2(B<D<N<C)$, giving defendants inalienability and additur options to deter plaintiff threats enhances bargaining efficiency. As summarized in Table 2, the defendant will opt for inalienability (but not additur), and the plaintiff will respond by electing monetary damages (D). There will be no chance of the inefficient performance actually occurring, as can happen if bargaining fails in the shadow of a credible performance threat. Additionally, the plaintiff and the defendant at most would need to bargain over any uncertainty in the ultimate size of court-awarded damages (D) and over how to split the total costs avoided by not having an actual trial. This latter negotiation is likely to be more efficient because the parties will have better information about the much smaller issues at stake. 95

When plaintiff performance threats arise in Range 1 (or when the defendant is uncertain whether $B$ is greater or less than D), however, it is ambiguous whether giving defendants inalienability and additur options would improve ex post bargaining efficiency. For example,

${ }^{95}$ We might, however, imagine situations in which the parties have better information about $C$ and $B$ than they do about what a jury might award as $D$. 
imagine the following Range 1 scenario:

Both the plaintiff and the defendant know that the defendant's $C$ has unexpectedly risen to $\$ 150$. The defendant is not sure of the exact value of the plaintiff's $B$ but she believes that it is equally likely to be any value above $\$ 0$ but below $\$ 100 .^{96}$ The parties also both know that a court would only award nominal damages which for simplicity we assume to be $\$ 0$.

Under these assumptions, the plaintiff will threaten an inefficient injunction, and the defendant knows that damages are in Range 1 (D $=0<\mathrm{B}<100<\mathrm{C}=150$ ).$^{97}$ In the simpler model with full information discussed above, the defendant knew the exact size of $B$ and so could choose an additur amount (A) such that supplemented damages would exceed the plaintiff's valuation $(\mathrm{D}+\mathrm{A}>\mathrm{B})$. In this scenario, the defendant can ensure an efficient result by making the injunction inalienable and choosing an additur amount of slightly more than $\$ 100$. The plaintiff would then seek monetary damages, thus avoiding the possibility of inefficient performance.

The defendant, however, will often not have an incentive to announce such a high additur amount. Giving the defendant inalienability and additur options in a sense allows the defendant to make the plaintiff a take-it-or-leave-it offer. ${ }^{98}$ Defendants with the power to make take-it-or-leave-it offers-but who are imperfectly informed about the plaintiff's benefit of performance-will often find it to their advantage to reduce the additur amount so that there is some chance that plaintiffs will still opt for an inefficient (and now inalienable) in-

${ }^{96}$ In other words, the defendant knows only that $\mathrm{B}$ is uniformly distributed between $\$ 0$ and $\$ 100$.

${ }_{97}$ The bargaining inefficiencies produced in this model are similar to a stylized version of the Peevyhouse case discussed in DOUGLAS G. BAIRD ET AL., GAME THEORY AND THE LAW 224-32 (1994). The authors examine a situation in which there are two "types" of plaintiffs: a high-valuing type who places a subjective value of $\$ 800,000$ on land restoration, and a low-valuing type who values such reclamation at only $\$ 200,000$. The cost of restoration is commonly known in their model to be $\$ 1,000,000$. Id. at 224-26. As in this example, it is common knowledge that performance is inefficient, but plaintiffs with relatively high valuations nevertheless seek injunctions in equilibrium. For further discussion of this example, see Ian Ayres \& Eric Talley, Solomonic Bargaining: Dividing a Legal Entillement to Facilitate Coasean Trade, 104 YALE L.J. 1027, 1061 n.105 (1995) (discussing "exit options" in the context of Baird, Gertner, and Picker's Peeryhouse example).

${ }_{93}$ After the defendant chooses inalienability and announces an additur amount (A), the plaintiff must either accept the monetary offer (of $D+A$ ), or reject it (and thereby accept performance). Once the plaintiff takes or leaves the offer, the inalienability of the injunction ensures that there are no further negotiations. 
junction. ${ }^{99}$ Under the foregoing assumptions, for example, the defendant would minimize her expected payments by choosing inalienability and announcing an additur amount of only $\$ 75-$ meaning that twenty-five percent of the time the plaintiff would still choose an injunction that would result in inefficient performance. ${ }^{100}$

When a defendant is poorly informed about the plaintiff's benefit of performance, then a defendant additur option can lead to less efficient ex post outcomes. When the defendant knows relatively more about $B$ than the plaintiff knows about $\mathrm{C}$, however, inalienability and additur options will tend to produce more efficient bargaining even in Range $1 .^{101}$ In the extreme case, if the defendant knows $B$ precisely (but the plaintiff does not know $\mathrm{C}$ precisely), then defendant inalienability and additur options will eliminate the chance of inefficient performance, since the defendant will name an additur amount which slightly exceeds the plaintiff's benefit of performance and thus will deter the plaintiff from opting for an inalienable injunction. ${ }^{102}$ Allowing

${ }^{99}$ Strategic inefficiencies often arise when one side to a negotiation has bargaining power (such as having a monopoly on the right to make offers) and the other side has private information. See Ian Ayres \& Robert Gertner, Strategic Contractual Inefficiency and the Optimal Choice of Legal Rules, 101 YALE L.J. 729, 737-42 (1992) (providing an example of a commercial carrier with market power negotiating with shippers who have private valuation information).

${ }^{100}$ If the defendant chooses an additur $A$ of $\$ 100$, she will pay $\$ 100$ in damages $100 \%$ of the time; the plaintiff's benefit from performance $B$ is always less than $\$ 100$, so he will always opt for the $\$ 100$ in damages rather than the injunction. The defendant's expected payment if $A$ is $\$ 100$ will therefore be $1.0 * \$ 100=\$ 100$. In contrast, if the defendant chooses an $A$ of $\$ 25$, there is a $25 \%$ chance that the plaintiff's $B$ will be less than $A$, so there is a $25 \%$ chance that the plaintiff will opt for damages at a cost to the defendant of $\$ 25$. At the same time, there will be a $75 \%$ chance that the plaintiff will refuse $\$ 25$ and instead demand performance, which costs the defendant $\$ 150$. If the defendant offers an additur amount of $\$ 25$, she can therefore expect to spend (on average) $(.25 * 25)+(.75 * 150)=\$ 118.75$. In other words, under the assumptions of the above scenario, the defendant who chooses a total damage payment $A$ between 0 and 100 will have an $A \%$ chance of paying $A$, and a $(100-A) \%$ chance of paying $\$ 150$. She will choose $A$ to minimize her expected payment, which can be represented by the equation (.01A)A + (1-.01A) 150. The $A$ that minimizes the payment is $\$ 75$. If the defendant offers the plaintiff $\$ 75$ in damages, she can expect to pay out $.75 * 75+.25 *$ $150=\$ 93.75$.

101 Because the effect of giving defendants inalienability and additur options in Range 1 turns on whether defendants are relatively informed about the plaintiffs' benefit of performance (B), Table 2 characterizes the effect on ex post bargaining efficiency as ambiguous.

${ }^{102}$ Conversely, when the plaintiff knows more about the defendant's $C$ than the defendant knows about $B$, giving the plaintiff a remittitur option will tend to produce more efficient ex post bargaining. When given a remittitur option, a knowledgeable plaintiff can set a remittitur amount at a level that would eliminate bargaining by ensuring that performance threats are not credible. 
the plaintiff to obtain an alienable injunction, in contrast, might lead to inefficiency because a plaintiff who does not know the defendant's true cost of performance might demand such a high payment that settlement negotiations drag on or break down entirely.

In sum, granting defendant inalienability and additur options has attractive equity and efficiency characteristics. As an equitable matter, inalienability and additur options decrease the chance of overcompensation without increasing the chance of undercompensation. As a matter of efficiency, Table 2 suggests that deterring plaintiff threats will induce more efficient (1) ex ante defendant precautions and (2) joint risk-bearing. Moreover, if courts commit to damages which are generous but relatively insensitive to plaintiff reliance, deterring plaintiff threats with inalienability and additur options will also induce more efficient (3) ex ante plaintiff reliance and (4) ex post bargaining. We emphasize, however, that alternative and richer assumptions about ex ante decision-making might reverse some of these results. ${ }^{103}$ While comprehensive efficiency analysis is becoming increasingly difficult as lawyer/economists develop increasingly complex models, the appealing equity and efficiency attributes of the deterrence strategy make it a plausible reform candidate.

\section{MEANS OF ADDRESSING THREATS OF INEFFICIENT PERFORMANCE}

\section{A. Default Choice of Legal Regime}

As we have discussed, one means to deter performance threats is to implement a legal regime allowing the defendant inalienability and additur options. Since many performance threats can arise in contractual settings, however, it is necessary to analyze default choice. For example, should the default interpretation of contracts be that injunctions were meant to be inalienable (unless the parties opt out of inalienability) or should the default interpretation be that injunctions were meant to be alienable (unless the parties opt into inalienability)? This section argues that inalienability should be a default rule-meaning that all court-ordered injunctions should be presumptively inalienable unless (1) the parties explicitly contracted for alienability of injunctions ex ante or (2) the defendant unilaterally petitioned the

${ }^{103}$ For example, we do not consider the potential effects of inalienability and additur options on one party's decision to make investments that benefit the other party. See Che \& Chung, supra note 82 , at 54 , for a discussion of the role of damage rules in inducing such "cooperative investments." 
court to allow any injunction to be alienable at some point in the proceeding before the plaintiff irrevocably elected injunctive or monetary relief. $^{104}$ We do not argue that courts should change their practice about when to issue injunctions. ${ }^{105}$ Instead, we suggest that whenever a court decides that an injunction is appropriate, it should presumptively prohibit the defendant from discharging the injunction by paying the plaintiff. ${ }^{106}$

We must first justify why our proposal should be merely a default or presumptive rule instead of a mandatory feature of all injunctions. We see no reason based on either externalities or parentalism why plaintiffs and defendants should not be free to contract ex ante for alienable injunctions. ${ }^{107}$ Indeed, Table 2 shows that inalienability and additur may cause less efficient behavior on certain dimensions. For example, if damages are likely to be either undercompensatory or perfectly compensatory, then the parties may want to contract to give the plaintiff the option of seeking alienable injunctions in order to induce more efficient plaintiff reliance. ${ }^{108}$ When a plaintiff's ex ante reliance investments in increasing $B$ are particularly salient, the plain-

${ }^{104}$ As a legal matter, we would also enforce "firm" contractual inalienability provisions that waived defendants' options subsequently to waive inalienability. As we discuss above in the text accompanying note 98 , however, we predict that defendants will seldom have an incentive to waive inalienability ex post, so that such a provision would serve little purpose.

${ }^{105}$ As discussed above, we are attracted both to the "undue burden" rule which tends to deny injunctions when the defendant's cost $(C)$ is much greater than the plaintiff's benefit (B), see supra note $46-48$ and accompanying text, and to the equitable impulse to issue inefficient $(C>B$ ) injunctions nonetheless when jury-awarded damages (D) may be subcompensatory $(D<B)$, see supra notes 49 and accompanying text.

${ }^{106}$ To the extent possible, we have also suggested that when giving plaintiffs the choice between injunctive and monetary relief, courts should strive to assure that damages will be generous. Doing so can reduce the defendant's expected payment (compared to a regime with alienable injunctions) and has attractive equity and efficiency consequences. Specifically, the more uncertain the court's assessment of the plaintiff's $B$, the more generous the court's assessment of damage should be.

${ }^{107}$ In contrast, however, we do see externality reasons for restricting a plaintiffs ability to unilaterally opt for alienability after a dispute has arisen. A plaintiff does not bear all the costs of bargaining or failing to reach an agreement in the shadow of an alienable performance threat, and thus may choose alienability even when doing so is socially inefficient. In fact, the plaintiff is likely to bear a much smaller proportion of the costs, since the defendant must bear the cost of the inefficient performance.

${ }^{103}$ See supra text following note 87 (noting that where court-awarded damages are less than the plaintiff's benefit, inalienability and additur options undermine the plaintiff's incentives to invest efficiently); see also William P. Rogerson, Efficient Reliance and Damage Measures for Breach of Contract, 15 RAND J. ECON. 39, 50-51 (1984) (noting that ex post bargaining in the shadow of alienable injunctive relief may produce more efficient ex ante plaintiff reliance). 
tiff and the defendant might jointly decide to contract ex ante for alienable injunctions. ${ }^{109}$

Our proposal would also allow the defendant to unilaterally opt for alienability at any stage before the plaintiff made an irrevocable election between monetary and injunctive relief. ${ }^{110}$ This unilateral option would apply not only to contractual settings, but also to any noncontractual settings-such as the encroachment example-where a court might give the plaintiff the choice of injunctive or monetary relief. Our model suggests that defendants armed with an additur option would rarely petition the court to make any prospective injunction alienable. Without the additur option, defendants in Range 1 might opt for alienability, fearing that plaintiffs would prefer an inefficient, inalienable injunction to subcompensatory damages. Defendants who also have the additur option, however, can eliminate the risk of subcompensatory damages and hence their primary rationale for preferring alienability. Inalienability and additur in effect give defendants the right to make a take-it-or-leave-it offer. Game theory suggests that once a dispute arises, defendants would rarely have a rationale for forgoing the right to maintain an offer monopoly-which would have the same effect as opting for alienability. Concluding that defendants would rarely have an ex post incentive to choose alienability, however, is not a reason for limiting their ability to do so. We see neither externality nor parentalism rationales for prohibiting defendants from opting for alienability at an early stage of a dispute, and, accordingly, we would allow it. Parties already have the ability to contract ex ante to make damages the exclusive remedy in case of breach, thus prohibiting injunctions. It is arguably less of an intrusion on judicial power to give parties the limited option of making injunctions inalienable rather than the more expansive intrusion of stripping judges' injunctive power altogether.

Finally, it is useful to justify explicitly why the inalienability default that we propose is superior to an alienability default. ${ }^{111}$ As a descrip-

${ }^{109}$ For example, a factory contracting to buy an expensive but standardized machine may understand that there is relatively small risk that $\mathbf{C}$ will fluctuate but a substantial risk that $B$ will fluctuate if the buyer is not given adequate incentives to rely.

${ }^{110}$ As discussed above in notes 60-63 and accompanying text, a defendant must be able to commit to inalienability before the plaintiff elects a remedy in order to undermine the credibility of the plaintiff's performance threat.

${ }^{111}$ We also believe that the default additur amount should be zero dollars. When damages are compensatory or supercompensatory, the defendant would opt for a zero dollar default, and even when damages are likely to be undercompensatory, the court is ill-equipped to choose an additur amount. 
tive matter, the alienability of current injunctions is probably a default characteristic; parties under prevailing law can contract ex ante to waive the right to settle for money in lieu of performing an injunction. $^{112}$ This means that alienability is probably the current default, one that contractual parties could avoid by expressly contracting ex ante that any injunction that might issue would not be alienable.

We believe that an inalienability default is both more efficient and more equitable than the current alienability default. Our previous analysis of ex ante and ex post efficiency suggests that a majority of transacting parties are likely to substantively prefer inalienable to alienable injunctions. Thus, an inalienability default is likely to be the majoritarian default that minimizes the costs of contracting around. Moreover, in a world in which contracting parties rarely address whether or not injunctions will issue, much less whether such injunctions should be alienable, we predict that few parties would contract around either default. To the extent that there are some parties that would substantively prefer alienable injunctions and others that would substantively prefer inalienable injunctions, the choice of default will largely determine which type of failures to contract we see. Because we believe inalienability to produce more equitable payoffs, we also believe that failures to contract around an inalienability default promote equity, while failures to contract around alienability defaults conduce toward inequity (in the form of an enhanced probability that defendants will have to overcompensate plaintiffs).

\section{B. Considerations in the Decision to Grant Injunctive Relief}

This Article highlights several factors that should be considered in shaping injunctive relief. First, in deciding whether to grant plaintiffs the option of injunctive relief, courts should weigh the possible undue burdens that injunction performance might impose on defendants against the potential that monetary damages will undercompensate plaintiffs. ${ }^{13}$ Judges should continue to deny injunctions that impose undue burdens on a defendant as compared to the benefit to the

\footnotetext{
112 Some decisions suggest, however, that the alienability of injunctions is an immutable characteristic. See supra note 57.

${ }^{113}$ This is analogous to Judge Posner's balancing approach in American Hospital Supply Corp. v. Hospilal Products Ltd., 780 F.2d 589, 593 (7th Cir. 1986) (stating that a preliminary injunction should be granted if $\mathrm{P} * \mathrm{H}_{\mathrm{p}}>(\mathrm{I}-\mathrm{P}) * \mathrm{H}_{\mathrm{d}}$, where $\mathrm{P}$ equals the probability that the denial of the preliminary injunction would be an error, $\mathrm{H}_{\mathrm{p}}$ equals the harm the plaintiff would suffer if the injunction were denied, and $\mathrm{H}_{\mathrm{d}}$ equals the harm the defendant would suffer if the injunction were granted).
} 
plaintiff. Second, when issuing injunctions, courts should consider whether the injunction is meant merely to protect a plaintiff's right in its "use value" of performance or whether the injunction is meant to go further and protect the plaintiff's right to the "exchange value." The strongest justification for alienable injunctions exists when a defendant is found to have wrongfully acted to circumvent a plaintiff's right to bargain for a higher price. Thus, an injunction against a "willful" encroacher who unilaterally takes, instead of negotiating for the additional land, is more likely to be created to recreate the plaintiff's exchange value. Alternatively, an injunction against patent infringement may have not only the goal of protecting the patentee's use value (the value of practicing the invention), but also the goal of protecting the patentee's exchange value (the value of being able to negotiate for a high licensing fee by threatening not to license). ${ }^{114}$

When the court is merely granting an injunction to protect a plaintiff's right to the "use value" of performance, however, there is a stronger rationale for making the injunction inalienable. Courts ordering specific performance of contractual promises, for example, are most likely trying to give the plaintiff the benefit of actual performance and not a weapon to hold up the defendant for a payment that would put the plaintiff in a position dramatically superior to that resulting from actual performance. ${ }^{115}$ Contractors would rarely agree that when changed conditions make the defendant's performance inefficient that plaintiffs should be able to hold up the defendant for part of the inefficiency. ${ }^{116}$

${ }^{114}$ A problem with "exchange value" injunctions (that is, injunctions that aim to protect the plaintiff's right to block all non-consensual entitlement transfers) is that they can also overcompensate the plaintiff once the defendant has relied to her detriment on the taking. Thus, in the willful encroachment context, the amount that the plaintiff might have bargained for ex ante (before the encroaching wall was constructed) might be much less than the amount that the plaintiff might be able to bargain for in the shadow of an injunction ordering the wall to be removed (at substantial defendant cost).

${ }^{115}$ Injunctive orders concerning child custody are probably intended to protect parents' use value and not to create a bargaining chip that has an exchange value for the beneficiary.

${ }^{116}$ This is especially true when the inefficiency is caused by bad news (i.e., by an increase in a seller's expected costs). When the inefficiency is caused by good news (i.e., by an increase in a seller's opportunity cost of performance), however, there is a chance that the parties would agree to share in the good news. Thus, if a seller agrees to sell a widget for $\$ 100$ to an initial buyer and then, before performance, is due another buyer offers $\$ 2,000$ (an amount substantially above the initial buyer's valuation), the parties might negotiate for the initial buyer to participate in the good news. However, even here, if the initial buyer is relatively risk averse, the parties would tend to place the risk of a subsequent buyer showing up on the seller. See Polinsky, supra note 
Third, when giving plaintiffs an election between injunctive and monetary relief, courts should, to the extent possible, strive to make the monetary damages generous - that is, to assure that the damages are supercompensatory to the extent that they fall into Range 2. We have shown that generous damages combined with inalienable injunctions can actually reduce defendants' expected payment by inducing plaintiffs to opt for monetary damages. Supercompensatory damages can be both more equitable (moving the defendants' expected payment closer to make-whole compensation) and more efficient (producing more efficient ex ante incentives and ex post negotiations) than subcompensatory damages. This "generosity principle" also militates in favor of giving defendants an option to increase damages paid to plaintiffs through an additur.

\section{Judicial Review of Injunctive Settlements}

This Article's analysis also suggests that, as an alternative to the inalienability and additur options, courts should review the substance of injunctive settlements and reject those settlements where defendants pay an amount above any reasonable estimate of the plaintiff's possible benefit. ${ }^{117}$ Such a review might be similar to a court's evaluation of whether a liquidated damage amount is reasonably commensurate with a plaintiff's actual damages. ${ }^{118}$ Couched differently, a court might subject a proposed settlement payment (in lieu of injunctive performance) to the same remittitur analysis to which it would subject a jury award. ${ }^{119}$ Traditional judicial remittitur is an amount announced after

91, at 432 (discussing optimal risk allocation according to buyers and sellers' risk aversions). If the seller agrees to sell a widget for $\$ 100$ to an initial buyer and then the cost of performance rises unexpectedly to $\$ 10,000$, it is less likely that the buyer and seller would agree to allow the buyer to profit from this bad news. A legal regime permitting alienable injunctions would result in a higher variance of returns for both the buyer and the seller compared to a regime that only permitted expectation damages.

117 To be consistent with our earlier analysis, courts might, before asking plaintiffs to elect a remedy, ask defendants whether any injunction settlement should be subject to remittitur review.

${ }^{118}$ See Eric L. Talley, Note, Contract Renegotiation, Mechanism Design, and the Liquidaled Damages Rule, 46 STAN. L. REV. 1195, 1200-05 (1994) ("While courts potentially can invalidate underliquidated provisions, such maneuvers are much less frequent than the invalidation of overliquidated damages.").

${ }^{119}$ This analysis might require that judges listen to evidence about the level of potential damages since such evidence might not have been introduced in an injunction proceeding. Because the defendant ex post may have lower incentives to contest the plaintiff's evidence of professed benefits, it might even be appropriate for courts to assess the plaintiff's potential benefit of performance before issuing an injunction. This evidence might already have been introduced to satisfy the equitable prerequisite 
a jury has made its award, but it would be possible for courts in issuing an injunction to move first by simultaneously announcing a "settlement cap"- the maximum amount that a defendant might pay to discharge its injunctive duty. To the extent that this maximum is below the cost of performance threat point, it may mitigate the potential damage of a threat to perform inefficiently. Such a settlement cap would compress the bargaining range and, therefore, would likely produce a settlement amount that would more closely approximate make-whole compensation. ${ }^{20}$ Moreover, a price cap on alienable injunctions would make negotiations more efficient. For example, if it will cost a defendant $\$ 10,000$ to remove an encroaching wall, but actually removing the wall will only produce a benefit of $\$ 500$ for the plaintiff, then we can imagine how the parties would react to an alienable injunction with a $\$ 1000$ settlement cap. The plaintiff would likely elect injunctive relief, and the parties would quickly settle for $\$ 1000$. Because in the absence of a settlement the injunction will be performed, the judicial settlement cap does not change the parties' threat points. Rather, it limits the maximum amount that the plaintiff can hope to take away from such a negotiation. The likely result is that the parties will settle more quickly and with fewer bargaining breakdowns since there is no risk that the plaintiff will hold out seeking too much money.

Richard Epstein has explicitly argued for analogous price constrained bargaining games in other bilateral monopoly settings. ${ }^{121}$ In discussing the classic necessity context of dock usage during the exigencies of a storm, ${ }^{122}$ Epstein considers a legal regime that would give a dock owner "the absolute right to exclude, but if he chooses to ad-

that an injunction's burden is not undue in comparison with the plaintiff's benefit.

Our judicial remittitur proposal would require the parties to submit a proposed dollar settlement for judicial review. If the judge found the proposed amount to be unreasonably high and announced a lower remittitur amount, the plaintiff would then have the choice of demanding actual performance or accepting the lower remittitur amount. Giving the plaintiff this subsequent choice of performance assures that the plaintiff will not be undercompensated.

${ }^{120}$ To the extent that the parties' information about the cap was more certain than the parties' information about the defendants' cost of performance, most bargaining models would predict more efficient negotiations in the shadow of the cap.

${ }^{121}$ See RICHARd A. EPSTEIN, BARGaINING WITH THE STATE 57 (1993) (proposing that a dock owner have the absolute right to prevent a boat owner from using the dock, but if the dock owner permits the use of the dock then his compensation will be limited to the dock's rental value plus the damage caused by the boat).

${ }^{122}$ See Ploof v. Putnam, 71 A. 188, 189 (Vt. 1908) (holding that the plaintiff had the right to moor his sloop to the defendant's dock when a "sudden and violent tempest" arose that threatened the sloop and the lives of the people in it). 
mit, then it can only be on condition that he accept a compensation package limited to the rental value of the dock, plus the property damages caused by the owner." ${ }^{\text {223 }}$ Epstein sees that constrained price bargaining may be more efficient:

The use of this two-point distribution in effect rules out all intermediate solutions and thus makes it impossible to haggle over the price within some large range. In particular, the dockowner cannot insist on capturing the net worth of the shipowner, so that the bargaining problem is therefore effectively obviated.

A regime that legally constrains the price over which parties might bargain can thus avoid the ex post inefficiencies of bilateral monopoly haggling. When applied to the injunctive setting, capping the maximum amount that the defendant could pay in lieu of injunctive performance can not only streamline ex post negotiations, but also produce more efficient ex ante incentives and an arguably more equitable result.

Unlike our more extreme inalienability proposal, price regulation (of either the ex ante price cap or the ex post judicial remittitur kind) merely restricts the free alienability of injunctions. Restricting the price at which injunctions can be sold may also produce a more robust way to avoid inefficient injunctive performance. The defendant inalienability and additur options are crucially premised on gametheoretic predictions that plaintiffs will not seek injunctions if the benefits from actual performance can be made less than expected trial damages. The model predicts that few plaintiffs would seek injunctions once a defendant has opted for inalienability. If this deterrent effect does not come to pass, however, inalienable injunctions may lead to more inefficiency than the current alienability regime. Capping the amount that defendants can settle for may not deter as many plaintiffs from seeking inefficient injunctions, but it may lead to more efficient (and equitable) settlements in lieu of actual performance. Plaintiffs who represent to a court that they really want performance because monetary damages are inadequate have little reason to complain if the court allows the defendant to commit to a maximum price above which she cannot pay to buy back the injunction.

${ }^{123}$ EPSTEIN, supra note 121 , at 57.

${ }^{124}$ Id. 


\section{CONCLUSION}

In this Article, we have shown that people who are owed duties (potential plaintiffs) and people who owe duties (potential defendants) may threaten inefficient performance of those duties solely to improve their individual payoffs. Potential plaintiffs will at times threaten to force defendant performance by seeking injunctions instead of accepting monetary damages, while potential defendants will threaten to perform prior to breach instead of paying monetary damages.

Naive Holmesianism would suggest that when changed circumstances make some performance inefficient, a promisor merely has the choice between performing and paying damages. In many contexts, however, the promisor has not two, but three choices to consider: performing, paying damages, or negotiating in the shadow of a credible performance threat. We have shown that the amounts paid in the shadow of performance threats by plaintiffs or defendants can differ substantially from those amounts that would be assessed as legal damages. Moreover, appreciating the third possibility of negotiating in the shadow of performance threats leads to different predictions about the parties' preferences and behavior. Once we allow for the possibility of performance threats, we see that plaintiffs at times may perversely prefer lower expected damages-because lower damages may render defendant threats of inefficient performance incredible. And defendants at times may prefer higher expected damages-because higher damages may induce plaintiffs to opt for legal instead of equitable relief.

In the contractual context, threats to breach inefficiently are thought to be presumptively opportunistic. If fishermen in the middle of an Alaskan fishing season threaten to breach their promise to fish, not because they face unexpectedly high performance costs but solely to renegotiate a higher wage, the employees' actions are roundly condemned by the common law and commentators alike as acting in bad faith. ${ }^{125}$

Yet a similar consensus has not emerged with regard to threats to perform inefficiently. If a plaintiff seeks an injunction for perform-

125 See Alaska Packers' Ass'n v. Domenico, 117 F. 99, 102 (9th Cir. 1902) ("No astute reasoning can change the plain fact that the party who refuses to perform, and thereby coerces a promise from the other party to the contract to pay him an increased compensation for doing that which he is legally bound to do, takes an unjustifiable advantage of the necessities of the other party."). 
ance that he knows to be inefficient when expected damages are more than compensatory, he intentionally subjects himself to both the risk of prolonged negotiations and the risk that negotiations will fail and inefficient performance will ensue. If either risk were to materialize, costs could be high for all parties involved. In considering the effects of granting Walgreen an injunction to prevent another pharmacy (Phar-Mor) from renting space at a particular mall, Judge Posner acknowledged the inefficiencies that could result from negotiations:

Suppose the cost to Walgreen of facing the competition of Phar-Mor at the Southgate Mall would be $\$ 1$ million, and the benefit ... of leasing to Phar-Mor would be $\$ 2$ million. Then at any price between those figures for a waiver of Walgreen's injunctive right both parties would be better off.... But each of the parties would like to engross as much of the bargaining range as possible-Walgreen to press the price toward $\$ 2$ million, [Phar-Mor] to depress it toward $\$ 1$ million. With so much at stake, both parties will have an incentive to devote substantial resources of time and money to the negotiation process. The process may even break down, if one or both parties want to create for future use a reputation as a hard bargainer; and if it does break down, the injunction will have brought about an inefficient result. ${ }^{126}$

Judge Posner acutely understood that the costs of bargaining are likely to be positively correlated with the size of the bargaining range. When an inefficient injunction creates "a huge bargaining range[,] ... the costs of negotiating to a point within it might... [be] immense. ${ }^{127}$ As we have seen, bargaining in the shadow of either plaintiff or defendant performance threats can create just such large bargaining ranges. Bargaining in the shadow of payments based on expectation damages (as would occur under the inalienability and additur regime in Ranges 1 or 2) can be much more efficient because the bargaining range is likely to be smaller; the money to be saved by avoiding going to court (largely attorneys' fees) is much smaller and more easily estimated than the money to be saved from avoiding inefficient performance.

Courts award inefficient injunctions in part to reduce the possibility that relatively innocent plaintiffs will be undercompensated by monetary damages. By granting injunctions, however, courts may unwittingly increase the chance of overcompensation. Making injunctions presumptively inalienable and giving defendants the option of private additur reduces the risk of this overcompensation without in-

${ }^{126}$ Walgreen Co. v. Sara Creek Property Co., 966 F.2d 273, 276 (7th Cir. 1992).

127 Id. at 278 . 
creasing the chance that plaintiffs will be undercompensated. Less radically, courts might simply treat proposed defendant settlements (in lieu of injunctive performance) as jury awards and subject them to similar scrutiny for potential remittitur. We have shown that while efficiency is not unambiguously improved along every dimension, on the whole presumptive inalienability and defendant additur arguably enhance both efficiency and equity. Plaintiffs who represent to a court that they really want performance because monetary damages are inadequate have little reason to complain if the court allows the defendant to commit to either inalienability or a maximum price above which she cannot pay to buy back the injunction. ${ }^{128}$ Deterring plaintiff threats of inefficient performance can potentially reduce the costs of ex post negotiations and move the ex post payments closer to make-whole compensation.

${ }^{128}$ This Article suggests that when plaintiffs threaten inefficient performance (via injunctions) defendants should have offsetting options. Ayres \& Balkin, supra note 24, at 745 , analyzed the converse situation where a defendant threatened inefficient breach (via anticipatory repudiation) and suggested that plaintiffs should be given the offsetting option of being able to purchase specific performance. 